Nova Southeastern University

Florida

NSUWorks

Faculty Scholarship

Shepard Broad College of Law

Spring 1-1-2008

\title{
Playing in the Virtual Arena: Avatars, Publicity, and Identity Reconceptualized through Virtual Worlds and Computer Games
}

Jon M. Garon

Follow this and additional works at: https://nsuworks.nova.edu/law_facarticles

\section{Recommended Citation}

Jon M Garon, Playing in the Virtual Arena: Avatars, Publicity and Identity Reconceptualized through Virtual Worlds and Computer Games, 11 CHAPMAN L. REV. 465 (2008).

This Article is brought to you for free and open access by the Shepard Broad College of Law at NSUWorks. It has been accepted for inclusion in Faculty Scholarship by an authorized administrator of NSUWorks. For more information, please contact nsuworks@nova.edu. 


\section{9 \\ Chapman Law Review}

Volume 11

Spring 2008

Number 3

(C) 2008 by Chapman Law Review

\section{SYMPOSIUM ISSUE}

Publicity Rights in Bytes: Contemporary Issues in Entertainment and Sports Law

ARTICLES

PANEL 1: Publicity Rights and the Constitution: Privacy, Publicity, and the YouTube Phenomenon

Protecting Truthful Speech: Narrowing the Tort of Public Disclosure of Private Facts

Erwin Chemerinsky

Is Nominal Use an Answer to the Free Speech and Right of Publicity Quandary?: Lessons from America's National Pastime Raymond Shih Ray Ku

PANEL 2: Publicity Rights in Entertainment: From Second-Life to the Afterlife

$U-L a-L a$, What's Happened to Our California Right of Publicity? Eric Farber.

Playing in the Virtual Arena: Avatars, Publicity, and Identity

Reconceptualized Through Virtual Worlds and Computer Games Jon M. Garon

Intellectual Property Expansion: The Good, the Bad, and the Right of Publicity

K.J. Greene

Deciding Who Cashes in on the Deceased Celebrity Business

Kathy Heller 
PANEL 3: Publicity Rights in Sports: The Fantasy of Player Statistics Ownership

A Triple Play for the Public Domain: Delaware Lottery to Motorola to C.B.C.

Matthew J. Mitten.

The Fantasy of Athlete Publicity Rights: Public Fascination and Fantasy Sports' Assertion of Free Use Place Athlete Publicity Rights on an Uncertain Playing Field

Maureen C. Weston 581

\section{COMMENTS}

Escape from Darfur: Why Israel Needs to Adopt a Comprehensive Domestic Refugee Law

Holly Buchanan 601

Knowledge is Power: Consumer Education and the Subprime Mortgage Market

Allison De Tal 


\title{
Playing in the Virtual Arena: Avatars, Publicity, and Identity Reconceptualized Through Virtual Worlds and Computer Games
}

\author{
Jon M. Garon*
}

What sport shall we devise here in this garden,

To drive away the heavy thought of care?

William Shakespeare, The Tragedy of King Richard the Second, Act III, Scene IV

Serious sport has nothing to do with fair play. It is bound up with hatred, jealousy, boastfulness, disregard of all rules and sadistic pleasure in witnessing violence: in other words it is war minus the shooting.

George Orwell, Shooting an Elephant

INTRODUCTION: LET THE GAMES BEGIN ............................................. 466

I. CONTENT OWNERSHIP INSIDE COMPUTER GAMES AND VIRTUAL

WORLDS.

A. Origins ........................................................................ 468

B. First Amendment Protection for Computer Games and Virtual Worlds

C. Copyright's First Amendment Accommodations through the Idea/Expression Dichotomy and Fair Use.

D. Publicity Rights in Avatars............................................ 481

E. Publicity Rights: Accommodations for the First Amendment

F. Intersections with Trademark Fair Use and First Amendment Protection

G. Kirby's Ride through San Andreas: The State of Virtual World Protection

- Dean and Professor of Law, Hamline University School of Law; J.D. Columbia, 1988. This article was prepared as part of the Tenth Annual Chapman Law Review Symposium. I would like to thank my fellow panelists Kathy Heller, John Tehranian, Kevin Greene. Eric Farber, and the constitutional law panelists Erwin Chemerinsky, Jay Dougherty John Eastman, and Raymond Ku for the insights they shared throughout the symposium. 
II. WHERE SPEECH ENDS IN VIRTUAL WORLDS: WHAT CAN AND SHOULD BE REGULATED.

A. Where Publicity meets Free Expression: From Fair Use to Avatar-Jacking

B. Finding Balance among the Balancing Tests

C. Advertising inside the Game and the Need for Disclosure

D. Who Owns the Unauthorized Content, Anyway?

III. REORDERING ChaOS: COLlECTIVE BARGAINING AND BEST

PRACTICES FOR THE PROFESSIONAL NEIGHBORHOODS OF VIRTUAL WORLDS

A. Collective Bargaining as an Alternative to Regulation ...... 511

B. Expanding the Jurisdiction through Viral Distribution of the Agreements............................................................... 515

C. Best Practices for Everyone Else ..................................... 517

CONCLUSION

\section{INTRODUCTION: LET THE GAMES BEGIN}

Free agency started it all. Like the professional athletes a generation earlier, the elite computer gamers playing Madden Football wanted to move players from team to team. As with fantasy sports leagues, the gamers wanted to create rosters that matched up from week to week. A few wanted cross-over players to join in.

Soon, an online game developed. Clever programmers, illustrators, and sports aficionados created "PRO"( $(w$ 'w.pro.us), an interactive online gaming environment featuring virtual replicas of all starting professional athletes in football, baseball, basketball, soccer, hockey, tennis, boxing (full contact) and golf. The professional women's leagues were represented along with the men's leagues. Players could be used in their professional sport or imported to any of the other sports represented in the game. Lacrosse and gladiator fighting competitions were quickly added and proved some of the most popular. In some games, gamers would control entire teams while in others a gamer would control only his or her own character, allowing dozens of online gamers to participate at once. (This was difficult in football, but worked very well for gladiatorial fights in the Hippodrome and the Roman Coliseum.) As a default design, players generally wore their own team numbers and uniforms, but gamers could re-outfit the characters with any of the available professional, minor league, or university team indicia available in the "locker room." "Celebrity Death Match" became a popular mini-game.

Gamers were charged a monthly subscription fee, with additional costs for purchasing uniforms in the locker room. More entrepreneurial 
gamers set up design studios, selling original team logo designs, uniforms, equipment and weapons to enhance the play of the characters. Characters became "avatars." A gamer soon became able to edit the selected athlete, changing not only the team uniform but also the physical attributions of the player. Gamers increased the skill level for the characters and avatars on their team rosters through play or purchase of digital steroids and virtual growth hormones.

Nobody paid the players, their unions or the professional sports leagues. Pictures, descriptions and accounts of games - both copies and originals--were completely unauthorized.

In the final innovation before the lawsuits began, statistics from weekly fantasy sports play was added. Each week, the game "replayed" a highlight reel featuring play of fantasy teams against each other in fantasy leagues. With the nearly photographic quality of the animation, these fifteen minute highlight shows became as popular as some network broadcasts, appearing on YouTube and other websites.

PRO's popularity rivaled the Super Bowl. Thousands of gamers regularly spent time acting out their professional games; tens of thousands were heavy users. Millions of occasional gamers held accounts. Advertisers vied to purchase billboard space and naming rights to the virtual arenas and stadiums. Only the leagues, unions, players, networks, and videogame publishers objected.

The development of law within and about virtual worlds will remain a complex and conceptually challenging exercise for years to come. In many respects, the commercial and social interactions within virtual worlds are essentially the same as those interactions conducted face-to-face or over less engrossing technologies. In certain respects, however, the immersive nature of the virtual world redefines the nature of the experience.

Because virtual worlds mimic their brick-and-mortar counterparts, they exhibit commercial attributes unlike those of plays, television shows, or motion pictures. To the extent that there is commerce conducted within the medium, the historic separation between commercial conduct and expressive speech must be reconceptualized. In the first instance, such legal line drawing will necessarily be done with crude tools, so this article suggests that just as the theatre and motion picture industries turned to collective bargaining agreements to provide a more refined set of rules for professional content development, the entertainment content created in virtual worlds will benefit from similar collective bargaining solutions to legally difficult conundrums.

I The description used above distinguishes between avatars, which are individuated representations of the computer user from characters, which may be substantially the same identity for every computer user interacting with that aspect of the game. Like Mickey Mouse, Mario and Kirby are characters in a game rather than avatars representing the person operating the controls. 
Part I of this article provides an overview of virtual worlds and the legal framework for the regulation of content ownership. Part II addresses the tension between the speech and property rights associated with the participants in this new art form, identifying what the law suggests and how it should evolve through case law and legislation. Part III suggests the steps that can be taken through private ordering collective bargaining arrangements to further clarify the protections for professionals associated with this developing new medium.

\section{CONTENT OWNERSHIP INSIDE COMPUTER GAMES AND VIRTUAL WORLDS}

\section{A. Origins}

Since the advent of Pong, ${ }^{2}$ computer gamers have been searching for increasingly realistic - or, at least, photorealistic - experiences with their computer-generated content. As the technology has allowed for ever more realistic images, sound, and even tactile response, the gaming experience has grown far beyond high-score lists to become immersive, interactive environments. The "virtual environment is an interactive computer simulation which lets its participants see, hear, use, and even modify the simulated objects in the computer-generated environment."3 As described by the plaintiff in a legal action against Second Life, "many people 'are now living large portions of their lives, forming friendships with others, building and acquiring virtual property, forming contracts, substantial business relationships and forming social organizations' in virtual worlds such as Second Life."

Attributes of the genre include the ability to involve a very large number of simultaneous participants online through the Internet or other networking systems, and the ability for the participant to take on a character or role in the game. As some of these gaming environments involve millions of players, they are now coined, "massively multi-player online roleplaying game (MMORPG)." " The user-created characters in these worlds are referred to as "avatars," virtual representations of the players. ${ }^{6}$

2 "Pong, while not the first videogame, was the first coin-op arcade game and the first mainstream videogame that was available to almost everyone. Pong was the impetus for the development of the video gaming industry, almost single-handedly creating both the home and the arcade videogame markets." ClassicGaming.com's Museum: Atari Pong 1975-1977, http://classicgaming.gamespy.com (follow "Features: Console Museum" hyperlink; then follow "Pong" hyperlink) (last visited Mar. 16. 2008)

3 Woodrow Barfield, Intellectual Propert. Rights in Virtual Environments. Considering the Rights of Owners. Programmers and lirtual Avatars, 39 AKRON L. REV. 649, 649 (2006) (footnote omitted).

4 Bragg v. Linden Research, Inc., 487 F. Supp. 2d 593, 595 (E.D. Pa. 2007).

5 Barfield. supra note 3, at 650; see also Cory Ondrejka. Escaping the Gilded Cage: User Created Content and Building the Metaverse, 49 N.Y.L. SCH. L. REv. 81, 82 (2004): Caroline Bradley \& A. Michael Froomkın. Virtual W'orlds, Real Rules, 49 N.Y.L. SCH. L. REV. 103, 121 (2004).

n Bragg. 487 F. Supp. 2d at 595. The Bragg court also described avatars, explaining that 
The online role-playing games trace their lineage to Dungeons \& Dragons and the genre of role-playing games, in which participants would create characters who would navigate in the fictional worlds created and managed by "dungeon masters."7 In Dungeons \& Dragons, the players would give themselves the attributes of wizards, warriors, trolls, elves, and similar mythic characters. The interaction of the players and their characters would last in story arcs that could run for indefinite periods. There may even be some characters still in use from 1974 when the rules were first published. ${ }^{8}$ Character attributes were kept on note cards and interactions mediated through polyhedral dice.

The Dungeons \& Dragons genre moved to the online environment with games such as World of Warcraft, The Lord of the Rings Online: Shadows of Angmar, Warhammer Online, EVE Online, Anarchy Online, RuneScape, Rappelz, and Shadow of Legend. ${ }^{9}$ The genre also includes science fiction worlds such as The Matrix Online and Star Wars Galaxies. ${ }^{10}$

Professor Erez Reuveni suggests two attributes that define the MMORPG and virtual worlds, separating them from classic computer or their Dungeons \& Dragons predecessors." "Unlike traditional computer games, . virtual worlds are persistent and exist independently of any individual's presence. Virtual worlds exist in real time even after a specific player logs off, and a person's actions can permanently shape the virtual world." 12 While this is a literary distinction, the persistence and literary independence may also provide a framework for treating certain aspects of these works as distinct from novels, computer games, or motion pictures.

The persistence and literary independence of online role-playing games have spawned an entirely new genre from the fantasy worlds. In environments such as Second Life $e^{13}$, Moove ${ }^{14}$, Active Worlds ${ }^{15}$, or There ${ }^{16}$, the environment is a fantasy alternative to modern reality, with businesses, lounges, universities, and other brick-and-mortar equivalents. These environments are "near worlds," or alternate realities set in the present with on-

"[s]ince the advent of computers, however, 'avatar' is also used to refer to an Internet user's virtual representation of herself in a computer game, in an Internet chat room, or in other Internet fora." Id. at 595 n.3.

7 GameSpy.com. Magic \& Memories: The Dungeons \& Dragons Index, http://pc.gamespy. com/articles/538/538848pl.html (last visited Mar. 4, 2008).

8 Id.

9 All of these games can be found at http:/www.gamespy.com (last visited Mar. 16. 2008).

10 These two games can also be found at http:/www.gamespy.com. The science fiction roleplaying counterpart to Dungeons \& Dragons was Traveller, designed by Marc Miller for Game Designers' Workshop in 1977. Wikipedia. Traveller (role-playing game), http://en.wikipedia.org/wiki/ Traveller_(role-playing_gane) (last visited Mar. 4, 2008).

11 Erez Reuveni, On Virtual Worlds: Copyright and Contract Law at the Dawn of the Virtual Age, 82 IND. L.J. 261 (2007).

12 Id. at 265.

$13 \mathrm{http} / /$ secondlife.com.

$14 \mathrm{http} / /$ www. moove.com.

$15 \mathrm{http}: / / \mathrm{www}$ activeworlds.com.

$16 \mathrm{http}: / / \mathrm{www}$,there.com. 
ly modest changes from the world around us:

On the surface, Second Life is an online place somewhat similar to a Sims computer game, with buildings and roads and a population of avatars - cartoonish representations of users. Anyone can join, and users chat with each other, build houses, start businesses, go to concerts, and otherwise hang out together. The site is winning the attention of Internet heavy hitters who believe Second Life-or something like it-will evolve into a way to use the Net that is more like the way humans use the real world. In that way, it could mark a next great leap in the Net's accessibility. ${ }^{17}$

The attraction of virtual worlds comes from the technological opportunities to animate and enhance the interactions on a borderless, international landscape; the billions of dollars in revenue to be earned by the publishers and purveyors of these environments; and a growing cultural and commercial environment within each of the virtual worlds. Corporations, for example, are exploring the use of Second Life as a methodology and platform for employee training. ${ }^{18}$ As communications educator Montse Anderson noted, "programs such as Second Life have the potential to enhance learning because they allow people to interact with each other, rather than reading a manual." 19

The growth of virtual worlds is coming from a tremendous curiosity about these opportunities and a dramatic shift in the spending of the entertainment dollar. Games are projected to increase from nine to thirteen percent of annual entertainment spending per household by $2010 .^{20}$ The growth of virtual worlds has significant economic potential. The online game market has already surpassed both video and music sales. ${ }^{21}$ At present, the revenue is $\$ 4$ billion per year. ${ }^{22}$ "Strategy Analytics reckons the online games market could triple in size over the next five years, ballooning to $\$ 11.8$ billion." ${ }^{23}$ Even more than size, the online monthly service relationship allows for better management of accounts, increasing paying customers even in markets known for high piracy. For example, China is "where [World of Warcraft] has really taken off . . [With] 3.5 million players-paying up in a land where piracy has been a problem for other media companies, and demonstrating that it is possible to create online con-

17 Kevin Maney, The king of alter egos is surprisingly humble gu!: Creator of Second Life 's goal? Just to reach people, USA TODAY, Feb. 5, 2007 at 1B.

18 Andrew Johnson, Virtual Training: Phoenix Couple Launch Venture to Help Compantes Use Virtual World to Educate. Orient New Emplovees, ARIZ. REPUBLIC. Nov, 5, 2007, at B6.

19 Id.

20 Global Information, Inc., TV To Dominate Future Home Entertainment Spending, http://www.the-infoshop.com/press/itm34591_en.shtml (last visited Mar. 2, 2007). The report also predicts continued growth in television, particularly because of the digital delivery of the medium, while recorded music will continue to decline as a percentage of the household entertainment dollar. Id.

21 Matt Vella, Tolkien's liitual World Takes Off. Bus. WK. ONLINE, Sept. 28, 2007. http://www.busınessiveek.com/innovate/content/sep2007/jd20070928_550277.htm?chan=search.

22 Id.

$23 \mathrm{ld}$. 
tent that people will pay for." 24

The explosive growth of the revenue and the financial models that incorporate an active, engaged and participatory audience will deliver the ultimate media product. The benefit of persistence, literary independence and interactivity results in an ongoing user participation, which requires consumers to pay to remained subscribed. Moreover, the virtual environments create opportunity for advertisers to place goods and services in front of consumers in a variety of methods-which will fuel advertiser spending and consumer behavior. In addition to creating stories and audience entertainment, the persistence and literary independence of the medium provides an ideal environment in which to place advertising and products. ${ }^{25}$

Even in the medium of an interactive, virtual world, the distribution of producer-created content will continue to co-exist with participant-created content. The literary independence does not require that content come only from participants, so it is likely that producer-created content will play a significant role in many of the games and worlds popular within the genre. $^{26}$ As a variation of traditional theatre, the coexistence might manifest as the ability for both professional and amateur actors to utilize avatars to perform scripted productions. The entire canon of Shakespeare's plays will eventually be available as performed in animation-avatar performances by amateur and professional acting companies. Moreover, the choice of avatar will undoubtedly include the public's affinity for their stars. What better for an amateur actor than to portray the avatar of a famous performer? The aspiring professional actress will be able to shine with a nod to the femme fatales of the past? ${ }^{27}$

In the realm of sports, a simple version of this opportunity regularly takes place. Through the use of game controllers, players control professional athletes competing in all major professional sports. Madden Football, a game licensed by the National Football League and Players, Inc., the for-profit arm of the National Football League Player's Association, ${ }^{28}$ has

24 Dan Sabbagh, This virtual world yields very real profits, TIMES (London), Mar. 31, 2007, (Features), at 3.

25 But, despite the growth of gaming, the same studies suggest television will continue to dominate the entertainment medium. Television will increase from $44 \%$ of home spending to $53 \%$ of home spending. Global, supra note 20 . This suggests that watching television, whether on broadcast, cable, digital, or Internet, will continue to be a significant, if not dominant medium. Vella, supra note 2l.

26 Because producer-created content can be used to set professional norms through collective bargaining agreements, the presence of such content may be critical to the development of the medium. See infra Part IIl.

27 I imagine, as one such production, a restaging of King Lear played by James Earl Jones with a Darth Vader avatar and avatars from within the Star Wars cavalcade. Jar Jar Binks or Yoda can play the Fool and Princess Lela serves well as Cordelia, but there is only Queen Padme as another female character. So, casting for Regan and Goneril would be difficult.

28 Troy Wolverton, Electronic Arts Lands an NFL Exclusive, ThE STREeT.com, Dec. 13, 2004, http://www.thestreet.com/stocks/troywolverton/10198835.html; NFL Players Association, Players, Inc., http://www.nflpa.org/Departments/PlayersInc.aspx (last visited Mar. 4, 2008). 
become one of the most popular video games of all time. ${ }^{29}$ The football play calling, player control and immersive graphics make Madden Football only slightly less immersive than the virtual worlds or online role-playing games. ${ }^{30}$ To find players who are not under the Players, Inc. contract, former all-star players have been signed to participate in a competing product. $^{31}$ If not already possible, it is inevitable that the games genres will combine, allowing role-playing athletes to compete as teams using their favorite player's attributes.

From an economic and social standpoint, both law and industry must help determine whether the professional athletes and professional actors are entitled to compensation for being utilized as part of this entertainment product. Should an author have unbridled right to excerpt celebrities' identities from real life when creating upon a digital, interactive canvas? The athletes certainly care. "[M]any professional athletes have grown up playing sports video games. Players have even lobbied game companies to improve their digital representations." ${ }^{32}$ Such economic interests create powerful incentives to maximize ownership of content within the computer games and virtual worlds as well as protect the limitations on such content ownership.

\section{B. First Amendment Protection for Computer Games and Virtual Worlds}

The question of content ownership within computer games and virtual worlds assumes that the games and worlds are authorial, creative content, benefiting from the full panoply of legal protections. It has been long held that computer programs are literary works, protected by copyright laws. ${ }^{33}$ Beyond copyright, the law must reflect the changed paradigm of the computer games and virtual worlds. While the makers of Pong had no point of

29 Kevin Gemmell, Video Scouting-For sports fans and video gamers-even NFL plavers-it's a mad, mad, mad, mad. "Madden 2007" world, where graphics are good and a team's plowbook is as real as it gets, S.D. UNION-TRIB., Sept. 3, 2006, at C.

30 ld.

31 Seth Schiesel, With Famed Plạers, Game Takes on Madden's Turf, N.Y. TIMES, Sept. 17. 2007 at C3.

32 Id.

33 Williams Elec., Inc. v. Artic Int'l, Inc., 685 F.2d 870 (3d Cir. 1982). The House Report on the 1976 Act contains the following statement:

The term "literary works" does not connote any criterion of literary merit or qualitative value: it includes catalogs, directories, and similar factual, reference, or instructional works and compilations of data. It also includes computer data bases and computer programs to the extent that they incorporate authorshp in the programiner's expression of original ideas, as distinguished from the ideas themselves.

Id. at 875 n.4 (quoting H.R. REP. No. 94-1476, at 54 (1976)); see also Apple Computer, Inc. v. Franklin Computer Corp., 714 F.2d 1240 (3d Cir. 1983); Arthur R. Miller, Copvright Protection for Computer Programs, Databases, and Computer Generated Works: Is Anything New' Since CONTU?, 106 HARV. L. Rev. 977, 979 (1993); Pamela Samuelson, CONTU Revisited: The Case Against Copvright Protection for Compuler Programs in Machine-Readable Form. 1984 DuKE L.J. 663 (1984); cf. Midway Mfg. Co. v. Dirkschneider, 543 F. Supp. 466,479 (D. Neb. 1981) (copyright infringement involving PacMan, Galaxian, and Rally-X). 
view being espoused by their square ball or simple paddles, modern games can be violent, sexy, propagandistic, satirical or politically astute. ${ }^{34}$ At some point, the authors of these games tapped them for their expressive ability. The law has slowly followed suit.

The tardiness of the law to recognize the legitimate expressive interests of entertainment media is not a new concern. Since at least 1915, the question of the applicability regarding First Amendment rights has been reassessed by the courts with the introduction of each medium. In Mutual Film Corp. v. Industrial Commission of Ohio, ${ }^{35}$ a filmmaker facing a censor board challenged the state law claiming violations of free speech rights ${ }^{36}$ as well as interference with interstate commerce. ${ }^{37}$ "The Mutual"38 brought both state ${ }^{39}$ and federal free speech claims. ${ }^{40}$ Because the Supreme Court did not apply the First Amendment to the states until $1925,{ }^{41}$ the federal claim was exceptionally weak and technically beyond the power of the court. $^{42}$ Looking at the state speech protection, the court endeavored to assess the extent to which silent movies were protected as "speech, writing or printing"43:

Are moving pictures within the principle, as it is contended they are? They, indeed, may be mediums of thought, but so are many things. So is the theatre, the circus, and all other shows and spectacles; and their performances may be thus brought by the like reasoning under the same immunity from repression or supervision as the public press, - made the same agencies of civil liberty ....

We immediately feel that the argument is wrong or strained which extends the guaranties of free opinion and speech to the multitudinous shows which are ad-

34 E.g.. Chris Morris, Your Tax Dollars at Play: U.S. Army gets into the gaming business. You're paying for it, CNNMONEY.COM, June 3, 2002, http://money.cnn.com/2002/05/31/commentary/game_ over/column_gaming (describing computer game recruitng tools by the U.S. Army).

35236 U.S. 230 (1915).

$36 \mathrm{Id}$. at 239-40. The state law provision in question read as follows: "Only such films as are in the judgment and discretion of the board of censors of a moral, educational or amusing and harmless character shall be passed and approved by such board." Id. at 240 .

37 Id. at 239; see Jon M. Garon, Entertainment Lan', 76 TUL. L. REV. 559, 637-38 (2002) ("The interstate commerce argument was, in many ways, the more practical of the two arguments. Films were admittedly shipped in interstate commerce; the exhibitors often owned or were members of consortia that crossed state lines. Interstate commerce was a justiciable issue for the federal courts.").

38 The term "The Mutual" represented both the company and case. John Wertheimer, Mutual Film Reviewed: The Movies, Censorship, and Free Speech in Progressive America, 37 AM. J. LEGAL Hist. 158, 159 (1993).

39 Mut. Film Corp., 236 U.S. at 239. The Ohio Constitution also has a strong free speech clause:

Every citizen may freely speak. write, and publish his sentiments on all subjects. being responsible for the abuse of the right; and no law shall be passed to restrain or abridge the liberty of specch, or of the press. In all criminal prosecutions for libel, the truth may be given in evidence to the jury, and if it shall appear to the jury that the matter charged as libelous is true, and was published with good motives, and for justifiable ends, the party shall be acquitted.

OHIO CONST. art. I, $\S 11$.

40 Mut. Film Corp.. 236 U.S. at 230.

4 I Gitlow v. New York, 268 U.S. 652, 666 (1925).

42 Mut. Film Corp., 236 U.S. at 243.

43 Id. 
vertised on the bill-boards of our cities and towns . . and which seeks to bring motion pictures and other spectacles into practical and legal similitude to a free press and liberty of opinion.

The judicial sense supporting the common sense of the country is against the contention. $^{44}$

The Court took over three decades to reverse this position regarding such "spectacles" and other entertainment. ${ }^{45}$ In 1948, the Court articulated a new philosophy regarding the role of the First Amendment:

We do not accede to appellee's suggestion that the constitutional protection for a free press applies only to the exposition of ideas. The line between the informing and the entertaining is too elusive for the protection of that basic right. Everyone is familiar with instances of propaganda through fiction. What is one man's amusement, teaches another's doctrine. ${ }^{46}$

Relying on this expansive language, the Court eroded limitations on the First Amendment based on medium and, in 1952, the Court reversed the Mutual decision and protected motion pictures despite their largely commercial nature and their proclivity for greater evil - both accusations hurled today at computer games and virtual worlds:

It is urged that motion pictures do not fall within the First Amendment's aegis because their production, distribution, and exhibition is a large-scale business conducted for private profit. We cannot agree. That books, newspapers, and magazines are published and sold for profit does not prevent them from being a form of expression whose liberty is safeguarded by the First Amendment. We fail to see why operation for profit should have any different effect in the case of motion pictures.

It is further urged that motion pictures possess a greater capacity for evil. particularly among the youth of a community, than other modes of expression. Even if one were to accept this hypothesis, it does not follow that motion pictures should be disqualified from First Amendment protection. If there be capacity for evil it may be relevant in determining the permissible scope of community control, but it does not authorize substantially unbridled censorship such as we have here. ${ }^{47}$

Despite the Court's explicit rejection of the regulatory rationales in the context of motion pictures, modern legislatures have again introduced these arguments. ${ }^{48}$ The municipal bodies and state legislatures have attempted to ban or restrict certain aspects of video games, suggesting that the nature of the video game industry makes the content unworthy of constitutional protection or that the way in which these diversions are attractive to youth

44 Id. at 243-44; see Donald E. LiVely, Modern COMmunications LaW 10 (1991).

45 Joseph Burstyn, Inc. v. Wilson, Comm'r of Educ. of N.Y., 343 U.S. 495.502 (1952): Liv'ELY. supra note 44, at 10 .

46 Winters v. N.Y., 333 U.S. 507, 510 (1948).

47 Burstyn, 343 U.S. at 501-02 (citing Grosjean v. Am. Press Co., 297 U.S. 233 (1936); Thomas v. Collins, 323 U.S. 516, 531 (1945)) (footnotes omitted).

48 Video Software Dealers Ass'n v. Schwarzenegger. No. C-05-04188 (RMW), 2007 U.S. Dist. LEXIS 57472 at *25 (N.D. Cal. Aug. 6, 2007). 
make censorship more appropriate. ${ }^{49}$ They return to the same themes espoused in Mutual and Joseph Burstyn: "Several decades ago, the Supreme Court 'recognized that some believe motion pictures possess a greater capacity for evil, particularly among the youth of a community, than other modes of expression."

Courts have been steadfast in their refusal to allow prohibitions or criminal sanctions for the sale of ultra-violent or sexually explicit video games. ${ }^{51}$ For example, a 2000 St. Louis County, Missouri ordinance made "it unlawful for any person knowingly to sell, rent, or make available graphically violent video games to minors, or to 'permit the free play of' graphically violent video games by minors, without a parent or guardian 's consent." 52 In reviewing the ordinance, the Eighth Circuit Court of Appeals accepted the premise that "'material that contains violence but not depictions or descriptions of sexual conduct cannot be obscene.' Simply put, depictions of violence cannot fall within the legal definition of obscenity for either minors or adults." 53 The Eighth Circuit was quite mindful of the law's slow embrace of motion pictures as a form of expressive speech and took pains to avoid the same error:

We recognize that while children have in the past experienced age-old elemental violent themes by reading a fairy tale or an epic poem, or attending a Saturday matinee, the interactive play of a video game might present different difficulties

The fact that modern technology has increased viewer control does not render movies unprotected by the first amendment, and equivalent player control likewise should not automatically disqualify modern video games that are "analytically indistinguishable from ... protected media such as motion pictures."

We note, moreover, that there is no justification for disqualifying video games as speech simply because they are constructed to be interactive; indeed, literature is most successful when it "draws the reader into the story, makes him identify with the characters, invites him to judge them and quarrel with them, to experience their joys and sufferings as the reader's own[.]"54

49 E.g., LA. REV. STAT. ANN. $§ 14: 91.14$ (2008) (criminalizing video games that appeal to a minor's morbid interest in violence); St. Louis County Ordinance No. 20,193 (Oct. 26. 2000); REV. CODE INDIANAPOLIS/MARION. IND. \$\$ 831-1, 831-7 (2008).

50 Video Software Deulers Ass' $n, 2007$ U.S. Dist. LEXIS 57472 at *9 n.2 (quoting Interstate Circuit, Inc. v. City of Dallas, 390 U.S. 676, 690 (1968)).

51 E.g.. Interactive Digital Software Ass'n v. St. Louis County, 329 F.3d 954 (8th Cir. 2003): Am. Amusement Mach. Ass'n v. Kendrick, 244 F.3d 572 (7th Cir. 2001): Video Sofnture Dealers Ass 'n. 2007 U.S. Dist. LEXIS 57472; Entm't Software Ass'n. v. Foti, 451 F. Supp. 2d 823 (M.D. La. 2006); Entm't Software Ass'n. v. Hatch, 443 F. Supp. 2d 1065 (D. Minn. 2006); Entm't Software Ass'n v. Granholn, 426 F. Supp. 2d 646 (E.D. Mich. 2006); Entm't Software Ass'n v. Blagojevich, 404 F. Supp. 2d 1051 (E.D. Ill. 2005); Video Software Dealers Ass'n v. Maleng. 325 F. Supp. 2d 1180 (W.D. Wash. 2004).

52 Interactive Digital Softurare, 329 F.3d at 956.

$53 \mathrm{ld}$. at 958 (quoting Video Software Dealers Ass'n v. Webster, 968 F.2d 684, 688 (8th Cir. 1992)) (brackets omitted).

$54 \mathrm{ld}$. at 957 (quoting Wilson v. Midway Games, Inc., 198 F. Supp. 2d 167, 181 (D. Conn. 2002); Am. Amusement Mach. Ass'n v. Kendrick, 244 F.3d 572, 577 (7th Cir. 200l)) (second ellipses in onginal). 
The Eighth Circuit correctly refuses to make any First Amendment distinctions based on the interactive nature of the experience or of the form the new media is beginning to take. In correctly refusing to make such categorical exceptions, however, the decisions may be going too far in the opposite direction, cloaking the speech aspects of the interactive games with too broad a penumbra. The Eighth Circuit refused to allow St. Louis County to label graphic content "obscene" to minors, finding that historically only sexual content can be deemed obscene. ${ }^{55}$ In doing so, the court rejects the attempt to make a new category of unprotected speech for violent content that is sold to minors, despite the lawful regulation of nonobscene sexually explicit content sold to minors ${ }^{56}$ and commercial advertising directed at minors. ${ }^{57}$

The attempt to create additional categories of speech that can be regulated with regard to minors is certainly not new. Broadcast regulation has added mandatory children's programming ${ }^{58}$ technological blocking measures, ${ }^{59}$ viewer ratings, ${ }^{60}$ and Internet privacy protections. ${ }^{61}$ So much for "no law"-Congress has been quite active balancing the interests of speakers and their audience. ${ }^{62}$

Of course, as with the attempts to regulate sexually explicit content, any such laws must avoid creating an unlawful burden on the production of protected speech for adults when building these protections for minors. ${ }^{63}$ But given the wide-ranging nature of the content being developed (and described below), a much more nuanced approach will be needed to balance the various types of speech that will exist within the games and virtual worlds under development. In the context of sexually explicit material made available to minors, the Supreme Court found that there could be regulation which was sufficiently narrowly tailored to meet the governmental interest of protecting the minors which did not burden the free speech

55 See Interactive Digital Software, 329 F.3d at 958.

56 See Ginsberg v. New York, 390 U.S. 629, 639 (1968). The Eighth Circuit suggests that the content in question in Ginsberg "did not involve protected speech," Imteractive Digital Software, 329 F.3d at 959 , but such a suggestion is erroneous - creating a circular argument. While it is axiomatic that obscene materials (which have no constitutional protection for any reader) can be banned for children, the Supreme Court recognizes the state's interest in protecting children from harmful speech that is beyond regulation for adults. While a modem court may demand a more substantial standard than that of Ginsherg, the interest in protecting minors from harmful content has not been repudiated. $C f$. FCC v. Pacifica Found., 438 U.S. 726, 749-50 (1978) (coupling the "ease with which children may obtain access" with the concerns expressed in Ginsberg to justify special treatment of indecent broadcasting).

57 Pub. L. No. 101-437, 104 Stat. 996 (codified in scattered sections of 47 U.S.C.); see also Cass R. Sunstein, Television and the Public Interest, 88 CAL. L. REV, 499 (2000).

s8 Sunsten, supra note 57 , at 508 .

5947 U.S.C. $\$ 303(x)(2000)$.

60 Telecommunications Act of 1996, Pub. L. No. 104-104, $\$ 551$ (b)(1), 110 Stat. 56, 140 (1996) (was to direct insertion of 47 U.S C. $\$ 303(w)$, but did not become effective).

61 Children's Online Privacy Protection Act, 15 U.S.C. $\$ \$ 6501-03$ (2000).

62 But see Ashcroft v. ACLU, 542 U.S. 656 (2004) (granting preliminary injunction against Children's Online Protection Act); ACLU v. Gonzales, 478 F. Supp. 2d 775 (E.D. Pa. 2007) (permanent injunction of same).

63 Ashcroft, 542 U.S. at 665. 
rights of the adults. ${ }^{64}$ Whether geared towards violent content, sexually explicit content or both, some additional legal obligations may be placed on video arcades and retailers selling to minors. A balanced approach will be necessary that may begin with a robust protection of video games as expression, but, as with other media, the law must be an appropriate balancing of interests among First Amendment protection and limits on unprotected speech. ${ }^{65}$

\section{Copyright's First Amendment Accommodations through the Idea/Expression Dichotomy and Fair Use}

A second balancing occurs between First Amendment rights of the publisher and the intellectual property rights of any third parties who may have had some of their work exploited without permission. Copyright holders, trademark owners, athletes, celebrities, and performers holding publicity rights all seek to limit what publishers attempt to do with the proprietary content.

The balancing of interests for First Amendment protection has very different assumptions, depending on the nature of the rights at stake. Since computer games and virtual worlds involve copyright, trademarks and content regulation, in addition to the publicity rights emphasized in this article, a brief survey of each helps to illustrate the variety of tests used to balance these interests.

In addressing the limitations placed on a copyright holder's interest by the First Amendment, the Supreme Court had historically focused on the "idea/expression dichotomy," ${ }^{66}$ protecting the public 's right to use the idea expressed, but not the particular expression owned by the copyright holder. ${ }^{67}$ " $[\mathrm{T}] \mathrm{he}$ democratic dialogue-a self-governing people's participation in the marketplace of ideas - is adequately served if the public has access to an author's ideas, and such loss to the dialogue as results from inaccessibility to an author's 'expression' is counterbalanced by the greater public

64 E.g., Ginsberg v. New York, 390 U.S. 629, 639 (1968).

65 While not the focus of this article, I strongly question the assumption underlying the judicial conclusion that obscenity must be limited to sexually explicit material. While the precedential definition of obscenity is clear, throughout the Twentieth Century, the First Amendment has been expanded to cover additional categories of speech and reduced in the amount and type of content deemed outside of constitutional protection. Even when Joseph Burstyn, Inc. v Wilson overturned The Mutual, the Court reminded the parties that the "capacity for evil ... may be relevant in determining the permissible scope of community control." Joseph Burstyn, Inc. v. Wilson, 343 U.S. 495, 501-02 (1952). I do not suggest that cities and states should have unrestrained discretion, but neither does the Constitution suggest that the only content so repugnant as to be beyond First Amendment protection is sexually obscene speech. At the periphery of expressive content, regulators should be permitted an opportunity to meet constitutional thresholds to establish the case for a compelling state interest in the context of regulating access to content for young minors (e.g. rules for children under the age of 13 ).

66 Harper \& Row, Publishers. Inc. v. Nation Enters., 471 U.S. 539 (1985).

67 See, e.g., 17 U.S.C. $\$ 102$ (b). "In no case does copyright protection for an original work of authorship extend to any idea, procedure, process, system, method of operation, concept, principle, or discovery, regardless of the form in which it is described, explained, illustrated, or embodied in such
work." Id. 
interest in the copyright system." ${ }^{68}$ In Harper \& Row Publishers, Inc. $v$. Nation Enterprises. ${ }^{69}$ the Supreme Court endorsed this general approach. "[C]opyright's idea/expression dichotomy 'strike[s] a definitional balance between the First Amendment and the Copyright Act by permitting free communication of facts while still protecting an author 's expression." "'70 "Due to this distinction, every idea, theory, and fact in a copyrighted work becomes instantly available for public exploitation at the moment of publication." $" 71$

Dr. Michael D. Birnhack, writing in the Nimmer copyright treatise, raised questions regarding the legitimacy of over-reliance on the idea/expression dichotomy:

Consider the photographs from the Vietnam War of the My Lai massacre. Here is an instance where the visual impact of a graphic work made a unique contribution to an enlightened democratic dialogue. No amount of words describing the "idea" of the massacre could substitute for the public insight gained through the photographs. The photographic expression, not merely the idea, became essential if the public was to fully understand what occurred in that tragic episode. It would be intolerable if the public's comprehension of the full meaning of My Lai could be censored by the copyright owner of the photographs. Here it would seem that the speech interest outweighs the copyright interest. ${ }^{72}$

Despite the importance of visually powerful images to the public debate, the publishers of most photographs retain the ability to demand payment for use of the copyrighted work. Despite the visually powerful image invoked by the treatise, however, few such images exist that do not also incorporate the ability of publishers to secure the rights to publish for a fee. ${ }^{73}$ Such an image only becomes iconic through public exposure and adoption within the public's consciousness.

Instead of using the First Amendment to create an additional, constitu-

68 4 NimMER ON COPYRIGHT \$ 19E.03 [A][2]; Suntrust Bank v. Houghton Mifflın Co., 268 F.3d 1257, 1264 (11 th Cir. 2001).

69471 U.S. 539 (1985).

70 ld. at 556 (quoting Harper \& Row, Publishers, Inc. v. Nation Enters., 723 F.2d 195, 203 (1983)).

71 Eldred v. Ashcroft, 537 U.S. 186, 219 (2003); see Feist Publ'ns, Inc. v. Rural Tel. Serv. Co. 499 U.S. 340, 349-50 (1991).

724 NIMMER ON COPYRIGHT \$ 19E.03[A][2].

73 But siee Rosemont Enters., Inc. v. Random House, Inc.. 366 F.2d 303 (2d Cir. 1966) (attempted use of copyright ownership to stop unauthonzed biography of Howard Hughes not permitted); New York Times Co. v. United States, 403 U.S. 713 (1971) (the "Pentagon Papers" case). In concurrence. Justice Brennan expressed the lack of any need to balance copyright interests. "[T]he Government is not asserting an interest in the particular form of words chosen in the documents. but is seeking to suppress the ideas expressed therein." Idl. at 726 (Brennan, J., concurring). But see Salinger v. Random Housc, Inc., 811 F.2d 90 (2d Cir. 1987) (infringement for publication of unpublished letters in biography resulting in less access to such unpublished resources): New Era Publ'ns. Int'l, ApS v. Henry Holt \& Co., Inc., 873 F.2d 576 (2d Cir. 1989) (same). In rejecting the lower court's rationale for refusing an injunction, the Second Circuit commented that "[t]he public would not necessarily be deprived of an "intercsting and valuable historical study, but only of an infringing one." New Era Publ'ns, 873 F.2d at 584 (quoting New Era Publ'ns, Int'l, ApS v. Henry Holt \& Co., Inc., 695 F. Supp. 1493, 1528 (S.D.N Y. 1988). 
tional limitation on the rights of copyright holders, courts have increasingly turned to the doctrine of fair use ${ }^{74}$ to assure that the public's access to socially or culturally important aspects of expressive works are not unduly restricted by the copyright owners. ${ }^{75}$ The Supreme Court has made this increased constitutional importance of fair use explicit in Eldred v. Ashcroft. ${ }^{76}$ There, the Court raised the implicit protections of fair use to the level of constitutional importance: "[T]he 'fair use' defense allows the public to use not only facts and ideas contained in a copyrighted work, but also expression itself for limited purposes. 'Fair use' thereby affords considerable latitude for scholarship and comment . and even for parody ..."77

Although fair use has been statutorily codified into four prongs, courts have been quite adept at reviewing the significance of the usage and the lack of legitimate access to the work as part of the analysis. For example, in refusing to enjoin the unauthorized sequel to Gone with the Wind, the Eleventh Circuit looked to the harm caused to the well-established classic novel against the public's interest in a unique approach to the wellestablished novel. ${ }^{78}$

The case closest to the My Lai massacre example comes from the famous Zapruder film, which serendipitously captured the assassination of John F. Kennedy. ${ }^{79}$ The owner of the copyright refused to license the images for use in the defendant's book. In response, the defendant used his access to the photographs to steal copies of the images for use in his own work. The district court acknowledged the misconduct of the defendant but focused on the elastic nature of the fair use doctrine, drawing the following conclusion:

There is a public interest in having the fullest information available on the murder of President Kennedy. Thompson did serious work on the subject and has a theory entitled to public consideration.

The Book is not bought because it

74

Notwithstanding the provisions of sections 106 and 106A, the fair use of a copyrighted work, including such use by reproduction in copies or phonorecords or by any other means specified by that section, for purposes such as criticism, comment, news reporting, teaching (including multıple copies for classroom use), scholarship, or research, is not an infrnngement of copyright. In determining whether the use made of a work in any particular case is a fair use the factors to be considered shall include- (1) the purpose and character of the use, including whether such use is of a commercial nature or is for nonprofit educational purposes: (2) the nature of the copyrighted work; (3) the amount and substantiality of the portion used in relation to the copyrighted work as a whole; and (4) the effect of the use upon the potential market for or value of the copyrighted work. The fact that a work is unpublished shall not itself bar a finding of fair use if such finding is made upon consideration of all the above factors.

17 U.S.C. $\$ 107(2000)$.

75 See Michael D. Bimhack, Copyright Law and Free Speech after Eldred v. Ashcroft, 76 S. CAL, L. REv. 1275, 1289-90 (2003).

76 Eldred v. Ashcroft, 537 U.S. 186. 197 (2003).

$77 \mathrm{Id}$. at 190 (internal citatıons omitted)).

78 Suntrust Bank v. Houghton Mifflin Co., 268 F.3d 1257, 1264 (1 lth Cir. 2001).

79 Time, Inc. v. Bernard Geis Assocs., 293 F. Supp. 130, 131 (S.D.N.Y. 1968). 
contained the Zapruder pictures; the Book is bought because of the theory of Thompson and its explanation, supported by Zapruder pictures.

There seems little, if any, injury to plaintiff, the copyright owner. There is no competition between plaintiff and defendants. Plaintiff does not sell the Zapruder pictures as such and no market for the copyrighted work appears to be affected. Defendants do not publish a magazine. There are projects for use by plaintiff of the film in the future as a motion picture or in books, but the effect of the use of certain frames in the Book on such projects is speculative. It seems more reasonable to speculate that the Book would, if anything, enhance the value of the copyrighted work; it is difficult to see any decrease in its value. ${ }^{80}$

Such an analysis provides an excellent solution to the problem posed by the My Lai photographs. In the situation where a license is available for purchase, then the presumption is that a publisher seeking to use the work should secure that license. Where the content is not available and used in a transformative manner ${ }^{81}$ such as to propound a new idea or theory, then such use should be worthy of fair use protection. ${ }^{82}$

A similar situation occurred when an unauthorized use of an artist 's evocative and graphic imagery in brochures objecting to "obscene art" was held a fair use. ${ }^{83}$ Fundraising brochures objecting to "'offensive' and 'blasphemous' art by the National Endowment for the Arts," used cropped images of David Wojnarowicz's works in an attempt to shock, offend, and motivate donors to object to the government-funded art. ${ }^{84}$ In such a situation, it is highly unlikely that the victim of such a campaign would voluntarily license his work to the proselytizer, so fair use provides a balancing of the interests of the artist and the organization objecting to the work. If there were any example where the First Amendment could be used as an independent tool granting access to the content, the political nature of the debate over the National Endowment of the Arts and the concomitant refusal by Wojnarowicz to allow such use could suggest that the First Amendment would be an independent ground to balance the interests. The court had no need to turn to an independent analysis using the First Amendment, however, because the elastic nature of the fair use doctrine provides more precedent and a more narrowly balanced framework than would a resort to constitutional first principles.

Copyright fair use makes explicit that "the effect of the use upon the

80 Id. at 146.

8I See Campbell v. Acuff-Rose Music, Inc., 510 U.S. 569,579 (a more transformative use will weigh heavily towards a finding of fair use because the use "adds something new, with a further purpose or different character, altering the first with new expression, meaning, or message .... [T]he more transformative the new work. the less will be the significance of other factors, like commercial$1 \mathrm{sm}$, that may weigh against a finding of fair use.").

82 Compure Los Angeles News Serv. v. KCAL-TV Channel 9, 108 F.3d 1119, 1122 (9th Cir. 1997) (finding the rebroadcast of "Beating of Reginald Denny" not transformative) with Los Angeles News Serv v. CBS Broad., Inc.. 305 F.3d 924, 941 (9th Cir. 2002) (finding the short use of a clip of the "Beating of Reginald Denny" in montage was (ransformatıve use).

83 Wojnarowicz y. Am. Family Ass'n, 745 F. Supp. 130, 142-43 (S.D.N.Y. 1990).

84 ld. at 133 . 
potential market for or value of the copyrighted work" 85 must be taken into account in determining the scope of fair use. The inclusion of this aspect of the fair use test creates an economic incentive to license copyrighted works for exploitation. Copyright holders are encouraged to license their works because of precedent that gives economic protection to the market-based licensing while generally granting broader fair use rights to third parties in situations where the copyright holder has withheld licensing opportunities. $^{86}$ In situations where the copyright holder refuses to license, the equities tend to shift towards fair use whereas in cases where the third party refuses to seek the license or pay the fee, the equities favor the rights owner.

Through the use of both the idea/expression dichotomy and fair use, copyright holders are free to exploit the exclusive rights of their work without unduly limiting the expressive rights of others. Though the copyright owners occasionally object to the uses made by others of their rights, the system works to reward innovation, protect the editorial integrity, and promote the marketplace of ideas. These concepts, in turn, have informed publicity rights jurisprudence.

\section{Publicity Rights in Avatars}

Publicity rights are the most recent of the intellectual property rights to be recognized under the law, evolving into an important economic resource for their creators and a tool to manage the editorial and commercial integrity of the goods associated with the celebrity exercising the right. As such, protections of the economic and associative rights are similar to those of copyright and trademark. "The right of publicity is an intellectual property right of recent origin which has been defined as the inherent right of every human being to control the commercial use of his or identity." 87 Athletes, actors, and other celebrities expend considerable effort to maximize the potential for licensing, commercial exploitation, and identities. Publishers, such as EA Sports, invest heavily in these relationships so that their titles achieve dominant market presence. ${ }^{88}$ But the economic interest only has market value if the legal interests are respected by third parties and enforced by the courts or other relevant bodies.

The protectible identity of a person is broadly defined. "[T]he Right of Publicity is generally understood to encompass any personal attribute that identifies a particular person." 89 California statutory law lists one's "name, voice, signature, photograph, or likeness," as the attributes of

8517 U.S.C. $\$ 107(2000)$.

86 See, e g. Harper \& Row. Publishers. Inc. v. Nation Enters., 471 U.S. 539 (1985).

87 ETW Corp. v. Jireh Publ'g. Inc., 332 F.3d 915, 928 (6th Cir. 2003).

88 See. e.g. . Gemmell, supra note 29 (describing the relationship between EA and the NFL in creating the video game Madden).

89 W. Mack Webner \& Leigh Ann Lindquist. Transformation: The Bright Line Between Commercial Publiciț. Rights and the First Amendmemt, 37 AKRON L REV. 171 (2004). 
identity. ${ }^{90}$ While some states have yet to address the cause of action, most states provide a statutory cause of action, a common law cause of action, or both. ${ }^{91}$ California's common law articulation is typical: "A cause of action for common law misappropriation of a plaintiff's name or likeness may be pled by alleging: (1) the defendant's use of the plaintiff's identity; (2) the appropriation of plaintiff's name or likeness to defendant's advantage, commercially or otherwise; (3) lack of consent; and (4) resulting injury."

The right of publicity is distinct from either an inchoate right to be free from defamation or an invasion of privacy. ${ }^{93}$ One's name or appearance in public does not give rise to a publicity rights claim. "It is only when the publicity is given for the purpose of appropriating to the defendant's benefit the commercial or other values associated with the name or the likeness that the right of privacy is invaded." There is also some inconsistency on whether publicity rights are limited to those individuals who have exploited their rights commercially - so called celebrities-or whether the rights are protected for all individuals. ${ }^{95}$ In both California and New

\section{0}

Any person who knowingly uses another's name, voice, signature, photograph, or likeness, in any manner, on or in products. merchandise, or goods, or for purposes of advertising or selling, or soliciting purchases of, products, merchandise, goods or services, without such person's prior consent, or, in the case of a minor, the prior consent of his parent or legal guardian, shall be liable for any damages sustained by the person or persons injured as a result thereof.

CAL. CIV. CoDE $\S 3344$ (West 2007).

91 Marshall Leaffer, Symposium: Interdisciplinany Conference on the Impact of Technological Change on the Creation. Dissemination, and Protection of Intellectual Property: The Right of Publicity: A Comparative Perspectrve, 70 ALB. L. REV. 1357, 1358 (2007) ("In the United States, the right of publicity is now found in most states either by statute or by common law interpretation"). See 1 J. THOMAS MCCARTHY, THE RJghtS OF PUBlicITY AND PRIVACY $\$ \$ 2: 1-: 2,6: 3,6: 8$ (2d ed. 2003).

92 Montana v. San Jose Mercury News, Inc., 34 Cal. App. 4th 790. 793 (Ct. App. 1995); see also Allison v. Vintage Sports Plaques, 136 F.3d 1443, 1447 (1 l th Cir. 1998). Another useful articulation of the elements which comprise the infringement of the right are derived from the Restatement (Third) of Unfair Competition: "(1) That defendant used plaintiff"s name as a symbol of his tdentity (2) without consent (3) and with the intent to obtain a commercial advantage." Doe v. TCI Cablevisıon, 110 S.W.3d 363. 369 (Mo. 2003) (en banc).

93

The history of the right of publicity is markedly diflerent from that of trademark rights. but the right is derived, in part, from the traditional law of unfair competition. A few early cases protected what is now recognized as the right of publicity under the rubric of unfair competition, but some courts view the right of publicity as a direct descendant of the right of privacy, a very different type of right in no way dependent upon its owner's commercial activities

1-2 GILSON ON TRADEMARKS $\$ 2.16$ (internal footnotes omitted).

But if the right of privacy is a component of a broader right of personality, as yet unrecognized under that label in American law but inchoslc in the theoretical basis for the law of privacy, then it is a suitable matrix from which other rights protective of the personality can evolve....

Edward J. Danich. The Right of Personality" A Common-Law'Bavis for the Protection of the Moral Rights of Authors, 23 GA. L. REV. 1. 75 (1988).

14 RESTATEMENT (SECOND) OF TORTS $\$ 652 \mathrm{C} \mathrm{cmt.} \mathrm{d} \mathrm{(1977).}$

$95 \mathrm{ld}$. 
York, for example, there is no distinction based on the prior use. ${ }^{96}$

Although the history of publicity rights in the United States can properly be traced back to $1905,,^{97}$ the modern age of licensing is better identified with the victory by Topps Chewing Gum, Inc., that allowed it to enforce exclusive rights in professional baseball players' identity interests to help it sell gum by packaging it with baseball cards. ${ }^{98}$

Topps began a vigorous program of signing individual standard form contracts with thousands of both major and minor league baseball players. Under these agreements, each player granted Topps an exclusive right to publish his name, picture, signature and biographical sketch "to be sold either alone or in combination with chewing gum, candy and confection or any of them." As consideration, Topps guaranteed the player a lump-sum payment of $\$ 125.00$ for each season in which either his picture was used or the player was an active member of a major league club. These contracts ran until Topps had made five years of payments to the individual player. ${ }^{100}$

The nature of the rights for baseball 'players' trying to control their economic interest for playing cards is not dissimilar to those same athletes and actors claiming a right to control their identities when used for commercial purposes in computer games and virtual worlds. As the right developed, it needed (and still needs) to be untangled from other personal tort claims, such as defamation, false light invasion of privacy, unfair competition, and misrepresentation. ${ }^{101}$

96 CAL CIV. CODE $\$ 3344$ (West 2007); N.Y. CIV. RIGHTS LAW $\S \S 50-51$ (McKinney 2002).

97 Pavesıch v. New England Life Ins. Co., 50 S.E. 68, 69-70 (Ga. 1905) (the first case to recognize the common law right of publicity in the United States). The common law doctrine was developed from the seminal law review artıcle which argued that a common law right of publicity had long existed at common law under various names. See Samuel D. Warren \& Louis D. Brandeis. The Right to Priva$c y, 4$ HARV. L. REV. 193 (1890). The common law right in New York was rejected by the Court of Appeals. See Roberson v. Rochester Folding Box Co., 64 N.E. 442, 447 (N.Y. 1902). New York adopted its Civil Rights Law to reverse the court's decision.

98 Haelan Labs, Inc. v. Topps Chewing Gum, Inc., 202 F.2d 866 (2d Cir. 1953); see also Fleer Corp. v. Topps Chewing Gum. Inc., 658 F.2d 139, 142 (3d Cir. 1981) (reviewing Topps” licensing history).

99 Fleer, 658 F.2d at 142.

$100 \mathrm{Id}$.

101

[A] man has a right in the publicity value of his photograph, $i$ e., the right to grant the exclusive privilege of publishing his picture, and that such a grant may validly be made in gross, i.e., without an accompanying transfer of a business or of anything else. Whether it be labeled a 'property' nght is immaterial; for here, as often elsewhere, the tag 'property' simply symbolizes the fact that courts enforce a claim which has pecuniary worth.

[2] This right might be called a 'right of publicity.' For it is common knowledge that many prominent persons (especially actors and ball-players), far from having their feelings bruised through public exposure of their likenesses, would feel sorely deprived if they no longer received money for authorizing advertisements, popularizing their countenances, displayed in newspapers, magazines, busses, trains and subways. This right of publicity would usually yield them no money unless it could be nade the subject of an exclusive grant which barred any other advertiser from using their pictures.

Haelan, 202 F.2d at 868. 
In Zacchini v. Scripps-Howard Broadcasting Co., ${ }^{102}$ the Supreme Court provided important recognition that publicity rights are a legitimate economic interest which can be recognized by states: ${ }^{103}$

[T]he State's interest in permitting a "right of publicity" is in protecting the proprietary interest of the individual in his act in part to encourage such entertainment. [T] he State's interest is closely analogous to the goals of patent and copyright law, focusing on the right of the individual to reap the reward of his endeavors and having little to do with protecting feelings or reputation. ${ }^{104}$

The Zacchini decision unequivocally established that state publicity rights were not automatically preempted by the First Amendment. The Court did not, however, wrestle with the challenge of the correct balancing test between these competing interests. ${ }^{105}$

In Topps, Zacchini, and other cases articulating publicity rights, the primary underlying assumption emphasized the commercial rights in one's likeness - that a person owns his or her identity for endorsing or advertising a product. ${ }^{106}$ The protection of this interest necessarily includes a protection of reputation since the endorsement of a poorly manufactured or dangerous product would directly harm the reputation of the person giving the endorsement. ${ }^{107}$ This should not blur the parameters of the right, however, but merely highlight the importance of protecting the use of the right as commercially important.

Courts have expanded the notion of commercial endorsement, however, to include more creative ways of taking unfair advantage of others. ${ }^{108}$ As a result, a bright line distinguishing commercial activities of advertising billboards and product packaging from expressive uses in newspapers, magazines, plays, films and books has been eroded as parties seek additional ways of exploiting the good will associated with celebrities for products unrelated to those celebrities. The distinction may be critically important to understand the rights of third parties to exploit celebrity identities:

[W] hether the use of a person's name and identity is "expressive," in which case it is fully protected, or "commercial," in which case it is generally not protected. For instance, the use of a person's identity in news, entertainment, and creative works for the purpose of communicating information or expressive ideas about

102433 U.S. 562 (1977).

103 Id. at 572 .

104 Id. at $\$ 73$ (footnote omitted).

105 See id. (recognizing the nght of publicity as a legitimate cause of action while failing to discuss the First Amendment implications).

106 See supra notes 98-105 and accompanying text; see also, e.g.. Wendt v. Host Int'l. Inc., 125 F.3d 806. 811 (9th Cir. 1997) (use of lıkeness as animatronic puppets in bars); Abdul-Jabbar v. General Motors Corp., 85 F.3d 407, 416 (9th Cir. 1996) (use of prior name for car commercial); Carson v. Here's Johnny Portable Toilets. Inc., 698 F.2d 831, 835-36 (6th Cir. 1983) (use of slogan for commode sales).

107 E.g. Stephanie Strom, .1 Sureetheart Becomes Suspect: Looking Behind Those Kathie Lee Lahels, N.Y. TIMES, June 27. 1996. at D1.

IIJ E.g.. Nemanı v. St. Louis Univ.. 33 S.W.3d 184, 185 (Mo. 2000) (en banc) (using a researcher's name in a grant application). 
that person is protected "expressive" speech. On the other hand, the use of a person's identity for purely commercial purposes, like advertising goods or services or the use of a person's name or likeness on merchandise, is rarely protected. ${ }^{109}$

The distinctions between commercial and expressive use has proven quite difficult to separate. There is wide disagreement on the interpretation and efficacy of the laws across jurisdictions. ${ }^{110}$ Because publicity rights are creatures of state law, both the articulation of the specific rights and limitations of the interest vary a great deal from state to state. ${ }^{111}$ In contrast, the concern regarding expressive use of identity is the extent to which it impinges on federal constitutional rights of free speech.

\section{E. Publicity Rights: Accommodations for the First Amendment}

The Zacchini decision unequivocally established that state publicity rights were not automatically preempted by the First Amendment. ${ }^{112}$ The Court did not, however, wrestle with the challenge of the correct balancing test between these competing interests. Instead, a variety of state and federal courts have evolved inconsistent and sometimes incompatible approaches to create the appropriate balancing of these interests. Despite a good deal of dicta from various courts looking to base their decisions on doctrine common across jurisdictions, three fairly distinct lines of decisions have developed.

In Comedy III Productions, Inc. v. Gary Saderup, Inc. ${ }^{113}$ the California Supreme Court imported the concept of transformative fair use from copyright law as a framework through which the rights of publicity and speech could be balanced, describing it as "at the heart of any judicial attempt to square the right of publicity with the First Amendment."114 The California Supreme Court attempted to build upon the copyright fair use doctrine as a method of separating fair use from protected speech. As it explained, "both the First Amendment and copyright law have a common goal of encouragement of free expression and creativity .. "115 Having identified fair use as the framework, the California court set out to create a rule under which courts and parties could operate:

When artistic expression takes the form of a literal depiction or imitation of a celebrity for commercial gain, directly trespassing on the right of publicity without adding significant expression beyond that trespass, the state law interest in protecting the fruits of artistic labor outweighs the expressive interests of the imitative artist. On the other hand, when a work contains significant transformative

109 Doe v. TCI Cablevision, 110 S.W.3d 363. 373 (Mo. 2003) (en banc) (citations omitted).

110 C.B.C. Distribution \& Mktg., Inc. v. Major League Baseball Advanced Media, L.P., 443 F. Supp. 2d 1077, 1084 (D. Mo. 2006) (discussing the right of publicity in various states).

III See, e.g., George P. Smith II. The Extent of Protection of the Individual's Personality Against Commercial Use: Toward A New' Property' Right, 54 S.C. L. REv. 1, 29 (2002)

112 Zacchini, 433 U.S. at 573.

113 21 P.3d 797 (Cal. 2001).

$114 \mathrm{ld}$. at 808 .

$115 \mathrm{Id}$. (citation omitted) (footnote omitted). 
elements, it is not only especially worthy of First Amendment protection, but it is also less likely to interfere with the economic interest protected by the right of publicity. As has been observed, works of parody or other distortions of the celebrity figure are not, from the celebrity fan's viewpoint, good substitutes for conventional depictions of the celebrity and therefore do not generally threaten markets for celebrity memorabilia that the right of publicity is designed to protect. ${ }^{116}$

The court in Comedy III recognized that it was not articulating a single new legislative decree for publicity rights. Instead, the court tried to articulate its reasoning in a variety of ways. "Another way of stating the inquiry is whether the celebrity likeness is one of the 'raw materials' from which an original work is synthesized, or whether the depiction or imitation of the celebrity is the very sum and substance of the work in question."117 This formulation emphasizes the relevance of the publicity rights to the output of the new author or artist. Incorporation of the identity interests remains essential for biographies, news reporting, social commentary, and many other forms of protected speech. ${ }^{118}$

Perhaps because the case was dealing with parody, in Comedy III, the court chose not to incorporate the entirety of fair use, but instead to incorporate various prongs of the statutory formulation. ${ }^{19}$ Parody cases may be where the tensions run the highest rather than where the fair use is most robust. When asking "whether a product containing a celebrity's likeness is so transformed that it has become primarily the defendant's own expression rather than the celebrity's likeness," 120 parodies of the celebrities are often the form of fair use that is most like the celebrity's likeness and the least transformed.

Influenced by the particular use before it, the court rejected incorporation of the fourth statutory fair use element, "the effect of the use upon the potential market for or value of the copyrighted work." 21 The limitation should be revisited because in many cases outside of parody, such as biography, news reporting or commercial endorsement, the potential market

116 Id.

117 Id. at 809.

118 The court's own catalog of copyright examples is highly instructive:

We emphasize that the transformative elements or creative contributions that require First Amendment protection are not confined to parody and can take many forms, from factual reporting (see, e.g., Rosemont Enterprises, Inc. v. Random House, Inc. (N.Y.Sup.Ct.1968) 58 Misc.2d 1, 294 N.Y.S.2d 122, 129, affd. mem. (1969) 32 A.D.2d 892301 N.Y.S.2d 948) to fictionalized portrayal (Guglielmi, supra, 25 Cal. 3d at pp. 871-872. 160 Cal. Rptr. 352, 603 P.2d 454; see also Purks v. Laface Records (E.D.Mich.1999) 76 F.Supp.2d 775, 779-782 [use of civil rights figure Rosa Parks in song title is protected expression] ). from heavy-handed lampooning (see Hustler Magazine v. Falwell (1988) 485 U.S. 46, 108 S. Ct. 876, 99 L. Ed. 2d 41) to subtle social criticism (see Coplans et al., Andy Warhol (1970) pp. 50-52 [explaining Warhol's celebrity portraits as a critique of the celebrity phenomenon] ).

Comedy $I I I, 21$ P.3d at 809 (citations in original).

$119 \mathrm{Id}$.

$120 \mathrm{ld}$.

$121 \quad 17$ U.S.C. $\$ 107(4)(2000)$ 
would be dispositive. One can never exploit the potential market for an unauthorized biography about oneself nor should one be able to be compensated for news reporting about oneself. In contrast, commercial endorsements of products or services have a robust market that should never give rise to claims that the endorsement was a transformative use of the celebrity's identity interests.

The California Supreme Court reaffirmed its approach in Winter v. DC Comics. ${ }^{122}$ Because the work in question was an expressive literary work, in this case a comic book, the court reiterated two important limitations for publicity rights it espoused in Comedy III:

We made two important cautionary observations. First, "the right of publicity cannot, consistent with the First Amendment, be a right to control the celebrity's image by censoring disagreeable portrayals. Once the celebrity thrusts himself or herself forward into the limelight, the First Amendment dictates that the right to comment on, parody, lampoon, and make other expressive uses of the celebrity image must be given broad scope. The necessary implication of this observation is that the right of publicity is essentially an economic right. What the right of publicity holder possesses is not a right of censorship, but a right to prevent others from misappropriating the economic value generated by the celebrity's fame through the merchandising of the "name, voice, signature, photograph, or likeness' of the celebrity." Second, "in determining whether the work is transformative, courts are not to be concerned with the quality of the artistic contributionvulgar forms of expression fully qualify for First Amendment protection. On the other hand, a literal depiction of a celebrity, even if accomplished with great skill, may still be subject to a right of publicity challenge. The inquiry is in a sense more quantitative than qualitative, asking whether the literal and imitative or the creative elements predominate in the work."123

In the comic book, Texas recording artists, Johnny and Edgar Winter were depicted as "villainous half-worm, half-human offspring." 124 Given the limitations placed on publicity rights that they not be used to censor disagreeable portrayals nor avoid vulgar expression, the two most significant complaints regarding the Winters' depictions properly became irrelevant. The court also made clear that subtleties of interpretation between parody and satire suggested by the Supreme Court in Campbell were inapplicable in the case of publicity rights. ${ }^{125}$ In doing so, the California court signaled a much wider berth should be given for the editorial use of publicity rights than fair use is afforded for copyright law. By determining that the use of the redrawn figures could be used for the comic books, the California court made clear that most insertions of caricatures of celebrities in other literary works would be considered a transformative use protected by the First Amendment.

12269 P.3d 473 (Cal. 2003).

$123 / d$. at 478 .

$124 \mathrm{ld}$. at 475 .

125 Id. at 479; $c f$. Campbell v. Acuff-Rose Music, Inc., 510 U.S. 569, 581 (1994); Dr. Seuss Enters., L.P. v. Penguin Books, 109 F.3d 1394, 1400 (9th Cir. 1997). 
In contrast to the transformative, fair use analysis adopted by California, an interpretation of an Oklahoma statute very similar to the California publicity statute did not feel free to incorporate fair use doctrine. ${ }^{126}$ Instead, in Cardtoons, L.C. v. Major League Baseball Players Ass ' $n .{ }^{127}$ the court directly balanced the interest of the First Amendment rights against the benefits of protecting publicity rights. ${ }^{128}$ As the Tenth Circuit commented, "In resolving the tension between the First Amendment and publicity rights in this case, we find little guidance in cases involving parodies of other forms of intellectual property."129 Absent statutory reference to fair use, the court found itself unable to incorporate the copyright law into the state 's publicity statute ${ }^{130}$ :

This case instead requires us to directly balance the magnitude of the speech restriction against the asserted governmental interest in protecting the intellectual property right. We thus begin our analysis by examining the importance of Cardtoons' right to free expression and the consequences of limiting that right. We then weigh those consequences against the effect of infringing on MLBPA 's right of publicity. ${ }^{131}$

Having set itself the task of determining the value and social utility of publicity rights, the Tenth Circuit opined that neither the economic incentives nor the non-economic incentives involved are all that compelling as compared to the benefits of parody. ${ }^{132}$ Summarizing the analysis of the Cardtoons decision, a district court described the balancing as:

Economic interests that states seek to promote include the right of an individual to reap the rewards of his or her endeavors and an individual's right to earn a living. Other motives for creating a publicity right are the desire to provide incentives to encourage a person's productive activities and to protect consumers from misleading advertising. But major league baseball players are rewarded, and handsomely, too, for their participation in games and can earn additional large sums from endorsements and sponsorship arrangements. Nor is there any danger

126 Cardtoons, L.C. v. Major League Baseball Players Ass'n. 95 F.3d 959, 968 (10th Cir. 1996).

127 Id.

$128 \mathrm{Id}$.

$129 \mathrm{Id}$. at 970 .

130 Id. at $970-71$.

131 Id. at 972 .

132 Id. at 976 (citıng Michael Madow, Private Onnership of Public Image: Popular Culture and Publicity Rights, 81 CAL. L. REV. 125, 128 (1993)). Because celebrities take on personal meanings to many individuals in the society, the creative appropriation of celebrity images can be an important avenue of individual expression. As one commentator has stated:

Entertainment and sports celebrities are the leading players in our Public Drama. We tell tales. both tall and cautionary, about them. We monitor their comings and goings, their missteps and heartbreaks. We copy their mannerisms, their styles, their modes of conversation and of consumption. Whether or not celebrities are the chief agents of moral change in the United States.' they certainly are widely used - far more than are our institutionally anchored elites-to symbolize individual aspirations. group identities and cultural values. Their images are thus important expressive and communicatıe resources. the peculiar, yet familiar idiom in which we conduct a farr portion of our cultural business and everyday conversation.

Madow, supra, at 128 (emphasis omitted) (footnotes omitted) 
here that consumers will be misled, because the fantasy baseball games depend on the inclusion of all players and thus cannot create a false impression that some particular player with "star power" is endorsing CBC's products.

Then there are so-called non-monetary interests that publicity rights are sometimes thought to advance. These include protecting natural rights, rewarding celebrity labors, and avoiding emotional harm. We do not see that any of these interests are especially relevant here, where baseball players are rewarded separately for their labors, and where any emotional harm would most likely be caused by a player's actual performance, in which case media coverage would cause the same harm. We also note that some courts have indicated that the right of publicity is intended to promote only economic interests and that noneconomic interests are more directly served by so-called rights of privacy. For instance, although the court in Cardtoons, conducted a separate discussion of non-economic interests when weighing the countervailing rights, it ultimately concluded that the non-economic justifications for the right of publicity were unpersuasive as compared with the interest in freedom of expression. "Publicity rights ... are meant to protect against the loss of financial gain, not mental anguish." We see merit in this approach. ${ }^{133}$

Although the outcome of the case is correct, the dismissal of the state's interest in protecting publicity rights was inconsistent with the Supreme Court 's decision in Zacchini and utterly dismissive of the legislative power of a state to recognize and regulate the property interests of its citizens. The difficulty caused by the Cardtoons approach is the categorical balancing of free expression against publicity rights rather than judging the particular use of identity interests as weighed against competing but significant governmental interests. Perhaps the best that can be said regarding the Cardtoons decision was the characterization by the California Supreme Court: "While Cardtoons contained dicta calling into question the social value of the right of publicity, its conclusion that works parodying and caricaturing celebrities are protected by the First Amendment appears unassailable in light of the test [adopted in California]."

Although not persuaded by Cardtoons, the Supreme Court of Missouri also rejected the California transformative fair use test and other jurisdictional precedents. ${ }^{135}$ It found that the California approach could lead to unintended and undesirable third party use. It rejected Comedy III because "the transformation or fictionalized characterization of a person's celebrity status is not actionable even if its sole purpose is the commercial use of that person's name and identity."136 The Missouri Supreme Court instead sought a more accommodating balance of interests to address expressive works used for commercial exploitation. The Court adopted Mark Lee's

133 C.B.C. Distribution \& Mktg. v. Major League Baseball Advanced Media, L.P.. 505 F.3d 818 ,

824 (8th Cir. 2007) (quoting Cardtoons, 95 F.3d at 973-76) (internal citations oinitted).

134 Comedy III Prods., Inc. v. Gary Saderup, Inc., 21 P.3d 797, 809 (Cal. 2001).

135 Doe v. TCl Cablevision. 110 S.W.3d 363. 374 (Mo. 2003) (en banc).

136 Id. 


\section{suggestion of a "predominant use test" 137 :}

If a product is being sold that predominantly exploits the commercial value of an individual's identity, that product should be held to violate the right of publicity and not be protected by the First Amendment, even if there is some "expressive" content in it that might qualify as "speech" in other circumstances. If, on the other hand, the predominant purpose of the product is to make an expressive comment on or about a celebrity, the expressive values could be given greater weight. $^{138}$

The Missouri Court also rejected the Restatement "relatedness" approach because it again objected to the categorical nature of the test. ${ }^{139}$ In the relatedness test, unauthorized parties are free to use another person's name or identity in a work that is "related to" that person. ${ }^{140}$ The Restatement provides the simplest test, harkening back to the axiomatic rule that publicity rights protect a person from others exploiting that person 's identity to sell a good or service without permission by stating that "if the name or likeness is used solely to attract attention to a work that is not related to the identified person, the user may be subject to liability for a use of the other's identity in advertising." 141 The relatedness test essentially boils down to a simple question whether the identity was used in an advertisement, in packaging, or on a product. ${ }^{142}$ If the identity was used in this fashion without permission, it is actionable. Used in almost any other manner, the use does not violate publicity rights. ${ }^{143}$

The Missouri Supreme Court required a careful balancing approach because it was upholding the finding of liability against a comic book author in a case not too dissimilar from Winter. In Doe 1: TCI Cablevision, ${ }^{144}$ Todd McFarlane created a comic book character using the name of St. Louis Blues hockey "enforcer" Tony Twist for a mafia goon and enforcer

$137 \mathrm{ld}$.

138 Id. (quoting Mark S. Lee, Agents of Chaos: Judicial Confusion in Defining the Right of Publicity-Free Speech Interface, 23 LOY. L.A. ENT. L. REV. 471, 500 (2002)).

139 Id.

140 Id. at 373 (citing ReSTATEMENT (THIRD) OF UNFAIR COMPETITION $\$ 47 \mathrm{cmt} . \mathrm{c}$ (1995))

141 RESTATEMENT (THIRD) OF UNFAIR COMPETITION $\$ 47 \mathrm{cmt}$. c. (1995))

142 In this simplistic but perhaps preferable approach, mugs, lunch boxes, and posters should be considered commercial products. Photographs, lithographs. and all expressive media-including newspapers, magazines, radio, television, motion pictures, video games, virtual worlds, and plays-would be expressive and outside of concerns regarding publicity rights claims. See RESTATEMENT (THIRD) OF UNFAIR COMPETITION $\$ 47 \mathrm{cmt}$ c (1995). Tee-shirts create the most difficult category because they often serve an expressive purpose, but are also often the source of copyright and trademark piracy. Given the First Amendment importance. tee-shirts might be best treated as expressive for publicity rights purposes, though still subject to copyright and trademark law protections. Whatever arbitrariness such an approach introduces, it removes the case-by-case analysis required by present law, which may result in a chilling effect and substantial self-censorship inevitable to avoid potential liability and the costs associated with litigation.

143 Such a formulation does not preclude lability for misrepresenting the endorsement or involvement of a person. False endorsements, inclusion of researcher's names in grant applications and other fraudulent actıvitıes would still be actionable under vanous unfair competition doctrines unrelated to publicity rights.

144110 S.W.3d 363 (Mo. 2003) (en banc). 
in the popular Spawn comic. ${ }^{145}$ Unlike the depictions in Winter, McFarlane used only the plaintiff's name, adding no demonic caricature of Twist. ${ }^{146}$ Nonetheless, on remand the court held a damage award of fifteen million dollars. ${ }^{147}$ The Missouri Supreme Court explained the result, at least in part, based on the marketing of the comic as hockey merchandise because of the steps taken to market Spawn to hockey audiences. ${ }^{148}$

The predominant test here creates a substantial risk of liability for authors well beyond the economic protections suggested by Zacchini or any other courts. ${ }^{49}$ The mere use of a name within an expressive comic book whether or not combined with an unrelated likeness would have been sufficiently transformative under Comedy III to avoid liability in California. The use would have also avoided any liability under the relatedness test of the Restatement since the use was not used to sell the comic, but was instead, related to the common attributes of this hockey player to mafia goons. Given the chilling effect of the damage award, Doe provides a strong illustration regarding the benefits of a narrow, bright line test as suggested by the Restatement.

In contrast, the Sixth Circuit has gone the furthest to reconcile the cases and provide thoughtful protection for both the First Amendment and publicity rights. In ETW Corp. v. Jireh Publishing, Inc., ${ }^{150}$ the commercial sports artist Rick Rush painted a montage of golf phenomenon Tiger Woods winning his first Masters Tournament in Augusta, Georgia in 1997. ${ }^{151}$ The ETW decision emphasized the Restatement's comments in helping to shape the contours of the right. The court accepted a theme from the Cardtoons decision: "The rationales underlying recognition of a right of publicity are generally less compelling than those that justify rights in trademarks or trade secrets." 152

145 Id.

$146 \mathrm{Id}$. at 366.

147 Doe v. TCI Cablevision of Mo., No. 9725-9415 B, 2004 WL 5294356M (Mo. Cir. Aug. 23, 2004) (Trial Order).

148 Id. at 371 (noting that "respondents marketed their products directly to hockey fans").

149 Had McFarlane used the name of Twist in those marketing efforts (as opposed to the mere use of the name of a character within the comic book), then the trademark balancing approach suggested in Rogers v. Grimaldi would have been more appropriate. See Rogers v. Grimaldi, 875 F.2d 994, 999 (2d Cir. 1989) and text accompanying infia note 188.

iso 332 F.3d 915 (6th Cir. 2003).

151 Id. at 918 . The painting was far more than a simple portrait:

In the foreground of Rush's painting are three views of Woods in different poses. In the center, he is completing the swing of a golf club, and on each side he is crouching, lining up and/or observing the progress of a putt. To the left of Woods is his caddy. Mike "Fluff" Cowan, and to his right is his final round partner's caddy. Behind these figures is the Augusta National Clubhouse. In a blue background behind the clubhouse are likenesses of famous golfers of the past looking down on Woods. These include Arnold Palmer, Sam Snead. Ben Hogan, Walter Hagen, Bobby Jones, and Jack Nicklaus. Behind them is the Masters lcader board.

Id.

$152 \mathrm{Id}$. at 930 (quoting RESTATEMENT (THIRD) OF UNFAIR COMPETITION, $\$ 46 \mathrm{cmt}$. C (2005)). 
The Sixth Circuit emphasized the need to adopt broad First Amendment protections for expression in order to foster a robust creative environment. Quoting Judge Kozinski from his dissent in White v. Samsung, ${ }^{153}$ the Court noted that:

Overprotecting intellectual property is as harmful as underprotecting it. Creativity is impossible without a rich public domain.... Intellectual property rights aren't free: They're imposed at the expense of future creators and of the public at large. ... This is why intellectual property law is full of careful balances between what's set aside for the owner and what 's left in the public domain for the rest of us .... 154

The Kozinksi dissent does not embrace the Cardtoons facial balancing of speech and property rights. It embraces the need to manifest a vibrant public domain and free speech ethos through a careful balance between the rights holder and the public. The Sixth Circuit has attempted to weave these various threads together in a more careful and nuanced manner than other jurisdictions, incorporating rather than rejecting the cases that have been decided in other jurisdictions:

We conclude that in deciding whether the sale of Rush's prints violate Woods's right of publicity, we will look to the Ohio case law and the RESTATEMENT (THIRD) OF UNFAIR COMPETITION. In deciding where the line should be drawn between Woods's intellectual property rights and the First Amendment, we find ourselves in agreement with the dissenting judges in White, the Tenth Circuit's decision in Cardtoons, and the Ninth Circuit's decision in Hoffman, ${ }^{155}$ and we will follow them in determining whether Rush's work is protected by the First Amendment. Finally, we believe that the transformative elements test adopted by the Supreme Court of California in Comedv III Productions, will assist us in determining where the proper balance lies between the First Amendment and Woods's intellectual property rights. ${ }^{156}$

By incorporating all the disparate sources of law into the analysis of Rush 's artwork depicting Woods' victory at Augusta, the Sixth Circuit sought to bring balance and harmony back to the law of publicity rights. The court went on to discuss the highly creative and transformative work created by Rush, which met the transformative test set out in Comedv III, and allowed for a finding that no publicity rights were implicated. ${ }^{157^{\circ}} \mathrm{De}$ spite the invitation to integrate the case law, courts continue to apply the various tests as set out by state and federal courts without the care or synthesis suggested by the Sixth Circuit. As a result, the precedential value of any particular case remains somewhat suspect.

153 White v. Samsung Elecs. Am., Inc., 971 F.2d 1395 (9th Cir. 1993) rehearing en banc denied, 989 F.2d 1512, 1513 (9th Cir. 1993) (Kozinski, J., dissenting).

154 White, 989 F.2d at 1513 (Kozinski. J., dissenting).

195 Hoffman v. Capital Cities/ABC, Inc., 255 F.3d 1180 (9th Cir. 2001) (doctored photograph of Dustin Hoffman in drag, standing in a pose simulating Tootste motion picture poster was held protected speech when used as a magazine cover) (footnote not in original quote).

$156 E T W .332$ F.3d at 936 ( footnote omitted).

$157 \mathrm{ld}$. at $936-37$. 


\section{F. Intersections with Trademark Fair Use and First Amendment Protection}

In almost every publicity rights case, the plaintiffs are also able to bring a cause of action for either a registered trademark ${ }^{158}$ or an unregistered mark under section 43(a) of the Lanham Act. ${ }^{159}$ Tiger Woods, for example, has a registered trademark in both "Woods" and "Tiger Woods,"160 while singer Tom Waits and athlete Kareem Abdul-Jabbar have raised unfair competition claims using section 43(a). ${ }^{161}$ Professional athletes in league sports may have registered trademarks in their names, while the professional sports leagues for which they play own the registered trademarks in the team names, logos, and related team indicia. Section 43(a) adds protection to stop a false endorsement, "which is likely to confuse consumers as to the [celebrity's] sponsorship or approval of the product."162

Like copyright law and publicity rights, trademark law limits the exclusivity afforded by trademark. ${ }^{163}$ First, any party who wishes to use trademarks can do so if such use does not create a likelihood of confusion. ${ }^{164}$ Moreover, as a defense to trademark infringement, trademark law generally recognizes two fair use exceptions and a First Amendment exception to allow third parties to exploit trademarks and trade dress without express permission. ${ }^{165}$

Under traditional trademark fair use, the words which are owned as a trademark can be used as fair use when accurately describing a company's own good or service. For example, although "VCR-2" is a legitimate trademark for Go-Video, the trademark holder cannot stop JVC from using VCR-2 to label the second VCR input jack on the back of its own devices. ${ }^{166}$ Trademark law was not "meant to deprive commercial speakers of

158 15 U.S.C. $\$ \S 1051-114 \ln (2000)$

15915 U.S.C. $\S 1125$ (a) (2000). The provision protects against false designation of origin as to the sources of goods and services and protection against the false advertising of goods and services. See, e.g., E.S.S. Entm't 2000, Inc. v. Rock Star Videos, Inc., 444 F. Supp. 2d 1012, 1027 (C.D. Cal. 2006).

160 ETW, 332 F.3d at $920-21$.

161 Abdul-Jabbar v. Gen. Motors Corp., 85 F.3d 407, 410 (9th Cir. 1996); Waits v. Frito-Lay. Inc., 978 F.2d 1093, 1107-08 (9th Cir. 1992); see also Midler v. Ford Motor Co. 849 F.2d 460 (9th Cir. 1988).

162 Waits, 978 F.2d at 1110.

16.3 E.g., ETW, 332 F.3d at 920. As an initial matter, trademark law "provides a defense to an infringement claim where the use of the mark 'is a use, otherwise than as a mark, ... which is descriptive of and used fairly and in good faith only to describe the goods ... of such party ...." Id. (quoting 15 U.S.C. $\$ 1115(b)(4))$.

164 KP Permanent Make-Up, Inc. v. Lasting Impression I, Inc., 543 U.S. 111, 117 (2004). Additional protections are available for "famous mark[s]," but such protection is beyond the scope of this artıcle. See 15 U.S.C. $\$ 1125(d)$ (2000).

16517 U.S.C. $\$ 107(2000)$.

166 In re Dual-Deck Video Cassette Recorder Antitrust Litig., 11 F.3d 1460, 1467 (9th Cir, 1993). For two other examples, see KP Permanent Muke-Up. Inc, 543 U.S. at 123 (2004) and Brother Records, Inc. v. Jardine, 318 F.3d 900, 905 (9th Cir. 2003) (Fair use "applies only to marks that possess both a primary meaning and a secondary meaning-and only when the mark is used in its primary descriptive sense rather than its secondary trademark sense."). 
the ordinary utility of descriptive words."167

The second form of trademark fair use is nominative fair use. A party may properly use the trademark of another to accurately describe the trademark owner's product. For example, an independent Volkswagen repair mechanic was allowed to use the trademark Volkswagen in its advertising to show the makes and models for which it provides service. ${ }^{168}$ Such accurate descriptions are allowed "even if the defendant's ultimate goal is to describe his own product." 169

The test for application of trademark fair use is in a state of flux. While the dominant case law has developed in the Ninth Circuit, recent Supreme Court jurisprudence has called the test into question. For purposes of comparing the approach to publicity rights, the tests of both the Ninth and Third Circuits are instructive.

Under the Ninth Circuit approach, the following characterization applies:

[W] here the defendant uses a trademark to describe the plaintiff's product rather than its own product, a commercial user is entitled to a nominative fair use defense provided the defendant meets three requirements: [T]he product or service in question must be one not readily identifiable without use of the trademark; only so much of the mark or marks may be used as is reasonably necessary to identify the product or service; and the user must do nothing that would, in conjunction with the mark, suggest sponsorship or endorsement by the trademark holder. ${ }^{170}$

The Third Circuit has modified the Ninth Circuit test with its own three-prong analysis:

Is the use of plaintiff's mark necessary to describe (1) plaintiff's product or service and (2) defendant's product or service? Is only so much of the plaintiff's mark used as is necessary to describe plaintiff's products or services? Does the defendant's conduct or language reflect the true and accurate relationship between plaintiff and defendant's products or services? ${ }^{171}$

167 KP Permanent Make-Up, 543 U.S. at 122, remunded to 408 F.3d 596 (9th Cir. 2005). On remand, the Ninth Circuit adopted the following set of factors for determining fair use:

Among the relevant factors for consideration by the jury in determining the faimess of the use are the degree of likely confusion, the strength of the trademark, the descriptive nature of the term for the product or service being offered by [the defendant] and the avallability of alternate descriptive terms, the extent of the use of the term prior to the registration of the trademark, and any differences among the times and contexts in which [the defendant] has used the term.

KP Permanent Make-Up, 408 F.3d at 609.

1 is Volkswagenwerk Aktiengesellschaft v. Church, 411 F.2d 350 (9th Cir. 1969).

169 Horphag Research, Ltd. v. Pellegrini, 337 F.3d 1036, 1040-4l (9th Cir. 2003) (quoting Cairns v. Franklin Mint Co., 292 F.3d 1139, 1152 (9th Cir. 2002)).

170 Downing v. Abercrombie \& Fitch, 265 F.3d 994, 1009 (9th Cir. 2001) (citung New Kids on the Block v. News Am. Publ'g, Inc., 971 F.2d 302, 308 (9th Cir. 1992)).

171 Century 21 Real Estate Corp. v. Lendingtrec, Inc., 425 F.3d 211, 228 (3d Cir. 2005). For a discussion of the case, see Graeme B. Dinwoodie \& Mark D. Janis, Lessons from the Trademark Use Dehate, 92 IOWA L. REV. 1703, 1709-10 (2007). 
Perhaps one of the reasons that the Ninth Circuit developed its particular articulation has been the extent to which the trademarks in question were related to identity issues, such as the band New Kids on the Block ${ }^{172}$, surfer legends, including George Downing and Paul Strauch ${ }^{173}$, actor, George Wendt ${ }^{174}$, and others for whom their trademarks were their identity. It may be that, whatever variation may result from the somewhat different articulations of the two competing formulations in general, there will be no meaningful difference in cases involving identity or publicity rights. In both categories, the nominative fair use question will turn on whether the use of the celebrity's identity to properly identify that celebrity suggests sponsorship and endorsement. This also answers the question whether "the true and accurate relationship" 175 is accurate or misstated as well as whether the extent to which the identity was used was only "reasonably necessary."176

A billboard for a miniature golf facility, saying, "Tiger Woods has never won on our Golf Course" would be accurate, but misleading. While it might be humorous to have a large photograph of Woods in despair as he missed a putt, the use of image and name would strongly suggest sponsorship-even if the text of the ad suggests otherwise. In contrast, a restaurant that posts a wall of photographs of famous celebrities taken as those celebrities are eating inside the restaurant accurately reflects that those celebrities dined in the facility, and their placement inside the restaurant rather than on billboards minimizes any likelihood of consumer confusion that the celebrities are endorsing the restaurant, except to the extent that the individuals depicted had dined there.

The differences in formulation may be significant in certain trademark contexts, but the differences should not affect the outcome of cases inside computer games and virtual worlds, particularly for trademarks related to identity interests.

One recent case involving computer games helps illustrate the impact on the nominative fair use approach. In E.S.S. Entertainment 2000, Inc. v. Rock Star Videos, Inc., ${ }^{177}$ a district court applied the nominative fair use approach of the Ninth Circuit to a claim for trademark and dress infringement when the plaintiff's marks "Play Pen" and "Totally Nude" were parodied within the video game Grand Theft Auto: San Andreas. ${ }^{178}$ The court did not take the simple expedient of dismissing the claim under the theory

172 New Kids on the Block. 971 F.2d 302.

173 Douning, 265 F.3d 994.

174 Wendt v. Host Int'l, Inc., 125 F.3d 806 (9th Cir.1997).

175 Century 21,425 F.3d at 228.

176 Downing, 265 F.3d at 1009.

177444 F. Supp. 2d 1012, 1027 (C.D. Cal. 2006).

$178 \mathrm{Id}$. at 1014 . The plaintiff's disputed the characterization of the depiction as parody. While it may be true the use could better be said to satirize Los Angeles than to parody the Play Pen"s name as trademark "Totally Nude," such distinction, if relevant at all, only affects the scope of copyright fair use under Cumphell v. Acuff-Rose Music, Inc., 510 U.S. 569 (1994). See id. at 1016 \& nn.13-16. 
that the defendant used the plaintiff's mark within an expressive work or under the theory that plaintiff failed to demonstrate any use of its marks as either a false association or false advertising with a product or service. Instead, the opinion emphasized nominative fair use. ${ }^{179}$

The court acknowledged the circularity of applying a nominative fair use analysis since "the lack of anything that suggests sponsorship or endorsement-is merely the other side of the likelihood-of-confusion coin." ${ }^{80}$ Not surprisingly, nominative fair use did not apply to the satirical use within the video game. The "strip club depicted in the game, the "Pig Pen" and copied trade dress did not attempt to refer to the plaintiff's products, "but only to describe their own product."181 Instead of applying an "other side of the coin" analysis, the court could have applied a likelihoodof-confusion analysis. This would have created far less difficulty in dismissing the claim, because there was no association with any good or service being offered by the plaintiff. ${ }^{182}$

Partially due to the confusion regarding nominative fair use, trademark law analysis requires an additional or alternative First Amendment analysis when expressive works are involved. The First Amendment limitation on trademark rights attempts to balance the limited property rights of the trademark holder with the public's interest in an open marketplace of ideas and the speaker's right to communicate. "[W]hen unauthorized use of another's mark is part of a communicative message and not a source identifier, the First Amendment is implicated in opposition to the trademark right." 183 Increasingly, courts have recognized that were they "to ignore the expressive value that some marks assume, trademark rights would grow to encroach upon the zone protected by the First Amendment." 184

The leading case articulating the balance of the trademark owner's rights and the expressive rights in creative works was decided by the Second Circuit in Rogers v. Grimaldi. ${ }^{185}$ Rogers involved a complaint by the famed actress Ginger Rogers regarding the title of a movie-Ginger and Fred-which referred to the motion pictures of Fred Astaire and Ginger Rogers as a metaphor, but did not involve or relate to either of the screen legends. Addressing the concern that Roger's name was being used for the film's title, the Second Circuit rejected both a narrow First Amendment exception-that there were "no alternative avenues of communication"186 - and the lower court's categorical assertion that trademark law

179 Id. at 1029.

180 Id. (quoting Brother Records, Inc. v. Jardine, 318 F.3d 900, 909 n.5 (9th Cir. 2003)).

181 Id. at 1036.

182 ld.

183 Yankee Publ'g v. News Am. Publ'g, 809 F. Supp. 267, 276 (S.D.N.Y. 1992).

184 Mattel, Inc. v. MCA Records, 296 F.3d 894, 900 (9th Cir. 2002).

185875 F.2d 994 (2d Cir. 1989).

186 Id. at 998; $c f$. Mut. of Omaha Ins. Co. v. Novak, 836 F.2d 397, 402 (8th Cur. 1987) (finding infringement when "adequate alternative avenues of communication exist"). 
was simply inapplicable to works of artistic expression. ${ }^{187}$ Steering clear of either extreme position, the court announced a balancing of interests between the trademark holder and the author:

We believe that in general the Act should be construed to apply to artistic works only where the public interest in avoiding consumer confusion outweighs the public interest in free expression. In the context of allegedly misleading titles using a celebrity's name, that balance will normally not support application of the Act unless the title has no artistic relevance to the underlying work whatsoever, or, if it has some artistic relevance, unless the title explicitly misleads as to the source or the content of the work. ${ }^{188}$

This test requires that there be a relationship between the literary content of a work and the trademark used in the title of the work as a condition of providing First Amendment protection for the speech. The use of a title in a work has at least some commercial aspects, which gives rise to the right to protect the public from fraudulent or misleading products and advertising. ${ }^{189}$ Such an approach is quite consistent with First Amendment jurisprudence that finds little value in commercial speech that is intentionally misleading. ${ }^{190}$

The Ninth Circuit has taken the same approach, extending Rogers to cases involving the use of the trademark "Barbie" in both a song title ${ }^{191}$ and in parody photographs. ${ }^{192}$ Many courts have also extended the Rogers balancing test beyond the titles of expressive works to the covers of books as well as to trademarks used within the content of the literary work. ${ }^{193}$ As the courts have suggested, "in deciding the reach of the Lanham Act in any case where an expressive work is alleged to infringe a trademark, it is appropriate to weigh the public interest in free expression against the public interest in avoiding consumer confusion." 194 The Sixth Circuit took a similar approach for the trademark aspects of Tiger Woods' name when used in conjunction with Rush's painting of the golfing victory at Augusta. ${ }^{195}$

The Rogers approach thus posits two reasons to restrict the use of a trademark or celebrity name. Either the mark has no artistic relevance to

187 Rogers, 875 F.2d at 999.

$188 \mathrm{Id}$.

189 See id. at 999 n.5 ("This limiting construction would not apply to misleading titles that are confusingly similar to other titles. The public interest in sparing consumers this type of confusion outweighs the slight public interest in permitting authors to use such titles.").

190 See, e.g.. Peel v. Attorney Registration \& Disciplinary Comm'n, 496 U.S. 91 (1990); In re R.M.J., 455 U.S. 191, 203 (1982); Cent. Hudson Gas \& Elec. v. Pub. Servs. Comm'n, 447 U.S. 557 (1980).

191 Mattel, Inc. v. MCA Records, 296 F.3d 894. 901 (9th Cir. 2002) (finding First Amendment protection for the song title, "Barbie Girl").

192 Mattel, Inc. v. Walkıng Mountain Prods., 353 F.3d 792, 807 (9th Cir. 2003).

193 Cliffs Notes, Inc. v. Bantam Doubleday Dell Publ'g Group, 886 F.2d 490, 494-95 (2d Cir. 1989): see also 2 THOMAS J. MCCARTHY, MCCARTHY ON TRADEMARK AND UNFAIR COMPETITION $\S$ 10:22 (4th ed. 2007).

194 Cliff.s Notes, 886 F.2d. at 494; see also Hoffman v. Capital Cities/ABC, Inc., 255 F.3d 1180, 1 183-84 (9th Cir. 2001) (balancing between right of publicity and the First Amendinent).

195 ETW Corp v. Jireh Publ'g, 332 F.3d 915, 937 (6th Cir. 2003). 
the underlying work, or the use of the mark "explicitly misleads as to the source or the content of the work."196

Returning to the marks in Grand Theft Auto: San Andreas, the use of plaintiff's marks-Pig Pen, Totally Nude and nude figure trade dress ${ }^{197}$ have relevance to a stylized Los Angeles streetscape in which the marks appear, and the marks do not suggest anything to mislead the players of the game as to the source or content of the game. With regard to the source of the game, the court pointed out that, "when First Amendment interests are implicated, the Rogers 'explicitly misleading' standard applies, not the traditional 'likelihood of confusion' test."'198

The test regarding consumer expectations is quite important for adjudicating the ability of artists and authors to use trademarks within expressive works. Given the commercialized nature of celebrity endorsements, general audiences may tend to assume that any use of a brand name, celebrity identity or other mark is done only with permission. There is little social utility, however, in allowing that normative expectation to reduce the range of free speech afforded to authors and artists. When focusing on the content within an expressive work, audiences are not harmed by the confusion. The audience member's choice to read, watch, or play has already been made. This was a key factor in the Rogers court, focusing on the title rather than on the content within the movie. The expressive use within the movie should have even greater First Amendment protection than the title. On the other hand, even protected speech has little utility when it is written to be explicitly misleading as to the source. A video game that claims to be the "approved and official game or web page," has little First Amendment protection if it is made without consent and is trying to hold itself out in a fraudulent manner to the public. ${ }^{199}$

\section{G. Kirby's Ride through San Andreas: The State of Virtual World Protection}

Courts do not formally attempt to consolidate the copyright fair use analysis, the trademark nominative fair use and First Amendment analysis, and the publicity rights fair use balancing tests. But the combination of these various tests, as applied in recent case law, suggests a strong trend towards protecting free expression and away from identity interests in computer games and virtual worlds.

196 Rogers, 875 F.2d at 999. 2006).

197 E.S.S. Entm`t 2000, Inc. v. Rockstar Videos. Inc., 444 F. Supp. 2d 1012, 1020-21 (C.D. Cal

198 Id. at 1045.

199 See, e.g., Mattel, Inc v. MCA Records, Inc., 296 F.3d 894. 900 (9th Cir. 2002). In contrast. the important distınction is how the fictional work is presented to the public. If someone wishes to produce a comic parody of commercialization by creating a television skit about the making of a TV commercial using athletes, the producer of the skit should not require permission of the athletes or manufacturers to depict real athletes or products in the parody. The skit producer is not intending to mislead the public into thinking the commercial or the endorsement is real. 
In Kirby v. Sega of America, Inc., ${ }^{200}$ a California appellate court addressed a right of publicity claim in the context of a Sega computer game named, Space Channel 5. ${ }^{201}$ Plaintiff, Kierin Kirby, lead singer of the retro-funk band "Deee-Lite," complained that her identity was used for the game. As described by the court, the similarities were quite difficult to imagine. The court had only modest respect for the publicity claims brought by Kirby, but nonetheless found that she raised triable issues of fact. ${ }^{202}$ The Kirby court rejected the plaintiff's suggested rule that the work relate to the person parodied by requiring the work to "say something-whether factual or critical or comedic" about Kirby the public figure in order to receive First Amendment protection. ${ }^{203}$ Despite the plaintiff's efforts, references to the Restatement test were thus rejected. ${ }^{204}$

The California court of appeal applied the transformative test from Comedy III - as interpreted by Winter-to find that Kirby was, at best, the raw material for Ulala, the character in Sega's game. ${ }^{205}$ The court noted that, "notwithstanding certain similarities, Ulala is more than a mere likeness or literal depiction of Kirby. Ulala contains sufficient expressive content to constitute a 'transformative work' under the test articulated by the Supreme Court."206 Such transformative changes included the anime style drawing, the height of the animated character, and the difference in dance style from Kirby. ${ }^{207}$ The concern raised by these cases is not the outcome, but the focus of the approach. As applied in Winter and Kirby, California's fair use test is evolving into a less helpful transformative test. As described in Kirby, the very act of rendering a live person's likeness into an avatar was transformative. This at least suggests that the rendering alone-the translation from photograph to avatar-would be sufficient to make the likeness a transformative fair use. Describing the depictions in Comedv III,

200 50 Cal. Rptr. 3d 607 (Ct. App. 2006).

$201 \mathrm{ld}$ at 609.

$202 \mathrm{ld}$. at 613 .

$203 \mathrm{ld}$. at 616 (internal quotations omitted).

204 See supra notes 132-34 (describing the Restatement test).

205 Id.

206 ld.

The similarities which gave rise to a trable issue of fact are not mentioned. Ulala resembles Kirby in certain respects. Certain of Ulala's characteristics and computer-generated features resemble Kurby's. Both images are thin, and have similarly shaped eyes and faces, red lips and red or pink hair. Both wear brightly-colored. formfitting clothing. including short skirts and platform shoes in a 1960's retro style. In addition, Ulala's name is a phonetic variant of "ooh la la," a phrase often used by Kirby and associated with Kirby. Final$\mathrm{ly}$, as the trial court pointed out, both Kirby and Ulala used the phrases, "groove," "meow," "dee-lish," and "I won't give up." These similarities support Kirby's contention her identity was misappropriated.

Id. at 613. The Kirby' court's description of similarities in the White case is helpful. White represented a "[n]onconsensual use of robotic image of celebrity Vanna White. dressed in wig, gown and jewelry regularly worn by White, turning letters on a game show set designed to look like the Wheel of Fortune, constitutes comnon law appropriation of celebrity's singular identity." Id. at 614 (citing White v. Samsung Elecs. Am., 971 F.2d 1395, 1399 (9th Cir. 1992).

2017 Kirhy, 50 Cal. Rptr. 3d at 613-14, 616. 
the Kirby court illustrates its understanding of the difference. "The artist who created [the Three Stooges drawings], while highly skilled, contributed nothing other than a trivial variation that transformed the drawings from literal likenesses of the three actors." 208 Such an interpretation creates a very low threshold for a transformative act. Moreover, since the transformative test does not take the commercial nature of the use into account, it may allow for much greater exploitation of an actor or athlete 's identity than had been historically permitted.

The purpose of incorporating fair use into publicity rights analysis was to assure that legitimate respect was given to the free speech rights of artists and authors who used the identity of the famous in their expressive works. As the test is evolving, however, it is losing sight of its role in creating a critical accommodation for expressive works.

Just as the court in Kirby extended Comedy III, the Eighth Circuit has extended Cardtoons in C.B.C. Distribution and Marketing v. Major League Baseball Advanced Media, L.P. ${ }^{209}$ In C.B.C., a fantasy sports operator brought a declarative action asserting its freedom to use "names, nicknames, likenesses, signatures, pictures, playing records, and/or biographical data of each player' in an interactive form in connection with its fantasy baseball products." 210 Although no visual images were used in connection with the for-profit fantasy league site, most other attributes of identity were utilized. The Eighth Circuit began the analysis by identifying the high social utility in access to the statistics of America's pastime:

The public has an enduring fascination in the records set by former players and in memorable moments from previous games .... The records and statistics remain of interest to the public because they provide context that allows fans to better appreciate (or deprecate) today's performances." The ... "recitation and discussion of factual data concerning the athletic performance of [players on Major League Baseball's website] command a substantial public interest, and, therefore, is a form of expression due substantial constitutional protection."

In addition, the facts in this case barely, if at all, implicate the interests that states typically intend to vindicate by providing rights of publicity to individuals.

[M]ajor league baseball players are rewarded, and handsomely, too, for their participation in games and can earn additional large sums from endorsements and sponsorship arrangements. 211

The court thus found that the players' claims were precluded by the First Amendment. ${ }^{212}$

The court saw little in either the economic or non-economic interests of the players to offset the public's interest in access to game statistics. 
Compare this result to a similar case decided in $1970 .{ }^{213}$ Throughout the 1960's, Negamco's Major League Baseball and Big League Manager Baseball were sold as sports fantasy games. The two games "employ[ed] the names and professional statistical information such as batting, fielding, earned run and other averages of some 500 to 700 major league baseball players, identified by team, uniform number, playing position and otherwise." 214 The unauthorized use of the information now protected by the First Amendment was barred in the earlier situation. ${ }^{215}$

The historical change in the expectation that players control the statistics of their play for purposes of fantasy games dictates the outcome of the litigation. If the court assumes that such an ownership right exists, as it did in Uhlaender, then a game manufacturer cannot exploit that right without permission. If the court assumes that no such right exists, as it did in C.B.C., then the game manufacturer is free to sell the game. No empirical justification is available to inform this assumption. It is an essentially arbitrary starting point, normatively based.

Again, a reflection on copyright fair use can provide a more nuanced approach as an analogy. ${ }^{216}$ Without challenging the finding that the public has a high interest in the baseball statistics, the assertion does not support a finding that the statistics should be controlled by the players or be available free to the public. Free access should reduce the costs to the public, but it may also reduce the reliability of the data gathered. The lack of ownership also means the lack of any quality control from the players. Copyright fair use, in contrast, would allow the court to assess the effect on the market. To the extent that the fantasy statistics are fully available through licensed channels to the public, the public need should be satiated. To the extent that the transaction costs involved in collecting the data are too high to license the information, fair use should provide an adequate remedy. Instead, the Eighth Circuit has made a value judgment regarding the publicity rights of the players as used in an unlicensed commercial fantasy sports business. This is perhaps yet another consequence of the California Supreme Court's rejection of portions of the fair use test in Comedy III.

The Restatement's relatedness test may provide a better explication regarding the shift of player statistics than is suggested by C.B.C. or Uhlaender. Board games (Uhlaender) and video games (C.B.C.) are both products. But websites are content, much closer to newspapers and televi-

213 Uhlaender v. Hendricksen, 316 F. Supp. 1277 (D. Minn. 1970).

$214 \mathrm{ll}$. at 1278. ("SCIENTIFICALLY COMPUTED [sic] Players are rated in every phase of baseball play. Each pitcher is different and each batter is different. You manage 520 big time players. Your strategy affects the outcome of every game. This game is Big. Colorful, and True. 220 pitchers and 300 fielders are included.").

$215 \mathrm{ld}$. at 1283 ("Defendants have violated plaintiffs' rights by the unauthorized appropriation of their names and statistics for commercial use.")

210 It is only an analogy, since copyright does not provide protection for any of the individual statistics and the players have not copyrighted work embodying the order, selection and arrangement of the statistics in any copyrighted fashion. See 17 U.S.C. $\$ 102(2000)$. 
sion than to lunch boxes or billboards. As websites and simple ball-andpaddle videogames converged into virtual worlds, the line was crossed and the works became wholly protected speech. Player data can no longer be protected as expression because the data has become the facts and ideas necessary for communication about the sport. Fantasy leagues are merely another method of that expression. It is the role of the content, which has changed, making C.B.C. correct for its age, just as Uhlaender was correct in its era.

Taken together, Kirby and C.B.C. reflect a strong swing away from protecting the identity interests of celebrities and towards free speech interests of producers for games and virtual worlds. The very nature of these tests suggests a movement away from protecting identity, significantly impacting products currently being sold and under development.

\section{WHERE SPEECH ENDS IN VIRTUAL WORLDS: WHAT CAN AND SHOULD BE REGULATED}

\section{A. Where Publicity meets Free Expression: From Fair Use to Avatar- Jacking}

Grand Theft Auto: San Andreas represents the state of the modern case law regarding computer games and virtual worlds. These games are entitled to First Amendment protection, thwarting city and state attempts to ban ultra-violent or socially repugnant works. They are expressive works, entitled to fair use and First Amendment protection that allows unauthorized use of intellectual property-copyrights, trademarks, and publicity rights - to be incorporated into their content. They are highly valuable commercial properties earning their owners tremendous revenue and setting the stage for a high stakes battle regarding the control of the intellectual property contained in these games. Against this backdrop, it will be useful to assess the legal consequences of the introductory example, www.PRO.us ("PRO"), a virtual world incorporating the best and worst aspects of Second Life, Madden NFL, and Grand Theft Auto.

In this hypothetical, Players, Inc.- - the for-profit licensing arm of the National Football League Players Association-will bring suit against the owners of PRO, and will also file take-down notices against the website hosting companies where the players' trademarks and publicity rights are being exploited without authorization. ${ }^{217}$

217 Such a lawsuit would be filed not just by Players, Inc., but also by all unions and leagues affected. The focus on a single plaintiff is for purposes of illustration only. The league and individual teams would bring trademark actions for the use of the registered trademarks, logos and mascots of the teams; broadcasters may have copyright claims for copying of television footage and still photography. as well as copyright claims for intermediate copying for the use of such photographs and footage into what later became the avatars and game graphics. The players would also be expected to bring defamation claims regarding unsportsmanlike activitıes and steroid use allowed in the game, and false light claims for the use of the identıty in gladiatorial games. This article provides no opinion as to the effica- 
In analyzing the hypothetical case, courts following the Digital Software, Kirby, E.S.S. Entertainment 2000, and C.B.C. line of cases will treat the game as an expressive work rather than merely a product. In recent cases attempting to ban ultra-violent games, courts have consistently accepted video games as expressive works. ${ }^{218}$ Since the various legal tests for fair use and First Amendment protection no longer rely on merely categorizing the game as expressive or commercial, however, this recognition of video games as expressive is merely the first step in the analysis.

Turning first to the use of the trademarks within the game, claims that PRO is unable to use these trademarks are directly comparable to C.B.C. Both the teams and the players will make trademark claims, but both will face similar challenges for protection.

Under trademark law, the teams and leagues would have a stronger claim than the players because the use of team names, logos, and colors for various fantasy leagues goes beyond the nominative fair use tests of the Ninth and Third Circuits. While the use of the player's professional affiliation would be necessary for the user to create one's team, there is less support for the claim that names, logos, or colors are necessary to build and play the team. Both the Third Circuit and Ninth Circuit nominative fair use tests focus on the necessity of the use, and the amount taken suggests that it is substantial. As a result, nominative fair use may provide little protection from the teams. The sufficiency and need for taking will be influenced by the expressive use made of these elements.

Publishers of PRO will assert that the game itself creates a parody of the leagues and the values of professional sports. To-the-death fighting, steroid availability, free agency, and interchangeability of players between sports all comment on the inherent nature of professional sport. Taken one step further, parody versions of these trademarks, created in a whimsical fashion like that in Cardtoons, would take less of the original and enhance the expressive elements.

The additional analysis required under the First Amendment further reflects a predisposition to protect free expression. It is quite difficult to parody the teams or players without access to the team names, colors, or logos. The public interest in the free expression will outweigh any concerns regarding likelihood of confusion. ${ }^{219}$ The satirical view of professional sports built into the game will have a strong influence on the First Amendment defense.

For the players, nominative fair use should eliminate any trademark

cy of those additional causes of action.

218 See. e g., Interactive Digital Software Ass'n v. St. Louis County, 329 F.3d, 954 (8th Cir. 2003); Video Software Dealers Ass'n v. Webster, 968 F.2d 684 (8th Cir. 1992); Am. Amusement Mach. Ass'n v. Kendrick, 244 F.3d 572 (7th Cir. 2001); Wilson v. Midway Games, 198 F. Supp. 2d 167 (D. Conn. 2002).

219 See, e g., Hoffman v. Capital Cities/ABC. Inc., 255 F.3d 1180.1187 (9th Cir. 2001). 
claims they may have. The names and images refer directly to the players. The relationship between the game and the players should be clear from the game play, use of disclaimers, and the sophistication of many in the online community. ${ }^{220}$ The transformative test applied in the Ninth Circuit to publicity rights, though not applying the same legal standard, is also helpful to use as a comparison. The Three Stooges T-shirts at issue in Comedy III were not transformative because, although they were skillful and careful reproductions of the likeness of the Three Stooges, they were merely accurate drawings, with nothing else added to the canvas, reflecting only a copy of the actors' images. ${ }^{221}$ In PRO, there is an overwhelming amount of additional content, manipulation of the images, the use of the images in the games, and the implicit social commentary of the players, leagues and sports. Like the image of Tiger Woods being embraced by golf's pantheon. the players' images are merely a part of the message communicated.

In the context of nominative fair use, courts following the reasoning of these cases will likely allow PRO to use the entirety of an identity. Given the extensive nature of the game and the comprehensive, highly transformative use to which the identity is put, celebrities and athletes should expect to have little ability to stop such use. Like an unauthorized biography, there is no amount of detail that crosses the line because of the context in which the raw material is used.

The publicity rights claims will follow the same line of reasoning for the transformative test of the Ninth Circuit and the related balancing test in the Sixth Circuit. Even assuming that the court did not follow Kirby's overzealous approach of characterizing the mere creation of the character as a transformative act, the use to which the PRO characters are put seems to be highly transformative. The users can manipulate the names and likeness to create new characters, cast those characters into a variety of sports, enhance the play of the characters, and evolve the people in a wide variety of ways. Such use bespeaks the "raw material" envisioned under California law. Given the protection afforded to free expression under Kirby and C.B.C., courts would find it difficult to rule against PRO even if the judges found the content undesirable.

To the extent that Doe v. TCI Cablevision creates any inconsistency in the court decisions, the facts of that decision render it far less persuasive. Doe emphasized that the commercial exploitation of hockey players occurred in a manner unrelated to the comic book, Spawn, but directly related

220 The game has violent aspects not appropriate for young children. Assuming steps are taken to verify that the game has a 13+ rating and the marketing is not geared at young children, the argument that the youth playing the game are more likely to be confused should have little weight. Teens generally seem quite discerning regarding their brands and do not require extra protection for tradenark confusion.

221 Comedy III Prods., Inc. v. Gary Saderup, Inc.. 21 P.3d 797, 810 (Cal. 2001) (finding that an artist accurate rendering of a celebrity image was not sufficiently transformative to receive First Amendment Protection). 
to marketing efforts to sell the comic books. ${ }^{222}$ A parallel between Doe and PRO would only exist if PRO utilized the players' likenesses to target the marketing of the game. Given the factually specific nature of Doe, there is little chance that Doe would sway a court's opinion.

Having said that, the outcome could depend on the jurisdiction in which the case is brought. The Missouri court would be highly critical of the analysis described above. As in Doe, the creators of PRO are emphasizing the game for the sports fan. The more a gamer knows of players and statistics, the more valuable the game features become. The use of real players is unequivocally intended to create a commercial advantage for the producers of the game. ${ }^{223}$ Applying "a sort of predominant use test,"224 PRO's producers would be hard pressed to establish that the predominant purpose of the game was "to make an expressive comment" on or about a player or players. ${ }^{225}$ This very narrow exception to publicity rights requires the object of the publicity rights claim to be the subject of the work at issue. Although taken as a whole, the players are the subject of the game, the emphasis of the work is on the game play, and not on the players. Real identities are not required to make the game work or even to comment on the violence or drug use associated with professional sports. Were a court to closely follow Doe, the players would be much more likely to have their identity rights protected.

The Doe approach highlights the economics underlying the game. Why should the players be forced to forgo income that will be made by third parties? By including the effect on the market, copyright fair use includes the ability to assess this question. But at present, only Zacchini reiterates this concern. ${ }^{226}$ Even under Zacchnini's approach, however, a court can distinguish the right of the player to control his or her performance from the right to recreate a user-generated performance based on attributes of the performer. Under a proper copyright fair use approach, courts would find fair use because a voluntary license is unlikely, given the nature of the parody in PRO.

\section{B. Finding Balance among the Balancing Tests}

The Missouri predominant use test goes too far in requiring a direct reference to the particular celebrity as a prerequisite to protecting free expression interests. On the other hand, California goes too far in excluding

222 Id. at 371.

223 See id. at 369.

224 Id. at 374.

225 Id. (quoting Mark S. Lee, Agents of Chaos: Judicial Confusion in Defining the Right of Publicity-Free Speech Interface, 23 LOY. L.A. ENT. L. REV. 471, 500 (2003)).

226 Zacchini v. Scripps-Howard Broad. Co., 433 U.S. 562, 576 (1977) ("The rationale for [protecting the right of publicity] is the straight-forward one of preventing unjust enrichment by the theft of good will." (quoting Harry Kalven. Jr., Privacy in Tort Law-Were Warren and Brandeis Wrong?, 31
LAW \& CONTEMP. ProBS. 326, 331 (1966))). 
the market effect from publicity fair use analysis. The full fair use analysis of copyright provides such a synthesis, as does the combination of trademark law's fair use, nominative fair use, and First Amendment defenses.

Copyright, of course, is not an entirely useful comparison. If the players were literary characters or comic book characters, then PRO would be an infringing work. The copyright in a celebrity's authorized avatar will have greater legal protection than the publicity rights available to the person behind the avatar. The extensive use of the characters in a video game would be an unauthorized derivative work. ${ }^{227}$ But the players are not themselves the work. The identity rights protected for humans are far less than the literary rights of characters protected for their authors.

Looking to a comprehensive fair use copyright analysis, the unauthorized use of the names and likeness would be balanced against the commercial nature of the game; the highly transformative use of the identities; the entirety of the identities taken; and the potential effect on the market. The effect on the market for publicity rights is an important factor under a copyright-style analysis. Although PRO does not substitute for watching professional sports, PRO does directly compete with Madden Sports and other licensed toys and games. The economic rights to the market will be affected by PRO. So either all of these products should no longer be protected, or PRO will require a license. This is an accurate reflection of fair use, but it also has problematic consequences.

A fair use approach to publicity rights ignores the transaction cost difficulties of such a doctrine. Fair use, as applied in the copyright context, is a highly fact specific regimen which may create a significant chilling effect on content that merely risks running afoul of infringement. Although this problem exists in copyright as well, centuries of practice and industry norms have allowed publishers to make many assumptions about the contours of fair use for purposes of quotations, reviews, news, commentary and many other unauthorized reproductions of third party content. The extent of fair use parody may be hard to predict, ${ }^{228}$ but many other forms of copyright fair use are largely routine.

In contrast, the two cases that have thus far attempted to create a new common law fair use doctrine for publicity rights are quite complex, and the role of such fact-specific rules in the mercurial worlds of computer games and virtual worlds makes such rule making more harmful than helpful.

A court applying a more comprehensive approach, such as the Sixth Circuit, would be more likely to find that the commercial nature of the

227 Cf. Pirone v. MacMillan, Inc.. 894 F.2d 579, 584 (2d Cir. 1990) (finding Babe Ruth's trademark and publicity rights in his name and likeness insufficient to stop use of photographs in a calendar).

228 See, e.g. Campbell v. Acuff-Rose Music. Inc.. 510 U.S. 569.579 (1994): cf. Dr. Seuss Enters. v. Penguin Books USA, Inc.. 924 F. Supp. 1559, 1575 (S.D. Cal. 1996), aff'd, 109 F.3d 1394 (9th Cir 1997). 
game and the ability of the publishers and the players to earn revenue, the comprehensive use of all attributes of identity, and the history of video game licensing would weigh heavily against the transformative nature of the game. Under such a balancing test, it would be hard to predict if PRO would be required to license the players' publicity rights or permit only fictional avatars to be used.

Only once the parameters of the online activities become clear can usefully predictive fair use rules begin to develop. Absent good fair use rules, the public is probably better served by a rejection of a cause of action for misappropriation of performances than it would be if such a cause of action existed.

\section{Advertising inside the Game and the Need for Disclosure}

Virtual worlds have the ability to include advertising and commercial speech within the game, an attribute that separates them from books and other literary works. ${ }^{22}$ Billboards in video games can be sold to advertisers, or change dynamically depending on the attributes of the game or the individual user. ${ }^{230}$ In PRO, for example, the producers of the game could show Gatorade on football sidelines since that product is commonly used in real-world football games. ${ }^{231}$ In the alternative, PRO's publishers could sell the branding rights to a particular company, create a fictional product, or have the product which is displayed be based on the computer browsing habits of each user towards the advertiser's products. In the not-too-distant future, the choice of drinks advertised in the video game could be based on the consumer preferences of the gamer. ${ }^{232}$ Needless to say, ability to affiliate particular products in the game to each gamer's user behavior will eventually have far-reaching economic consequences to reinforce brands and adjust marketing strategies. Such individuation of advertising would also change the relationship between the celebrity and the product to be advertised or endorsed.

The commercial endorsements and advertising in virtual worlds should be viewed as a form of commercialization rather than expressive

229 The motion picture industry and television industries are also increasing the incorporation of paid commercial content and product placement. The professional actors involved in these works have the ability to negotiate for an income stream from these revenues through collective bargaining agreements.

230 See, e.g., Derrik J. Lang, What if watching TV were like playing a game?, MINNEAPOLIS ST. Paul Star TriB., Dec, 23, 2007, at F3.

231 The technique of replacing advertising within movies has been both exploited and litigated. See Sherwood 48 Assocs. v. Sony Corp. of Am., 213 F. Supp. 2d 376, 377 (S.D.N.Y. 2002), aff'd, 76 Fed. Appx. 389 (2003) (digital replacements of billboards in New York's Times Square for Sony's Spiderman film were not infringing of the building"s trade dress).

232 This could be accomplished through brand surveys. cross-tabulation of the gamer to spending and purchasing habits tracked with credit cards and store affinity cards. or inferred through interaction with other computer content. In the latter case, for example, the company could assess the amount of screen time (or "stickiness") various products had for each gamer, then incorporate the advertising associated with the stickiest product on a user-by-user basis. 
speech because the gamer will be able to move directly to the commercial product on the Internet. Whether the commercial is directly linked to the product's website or whether the gamer must open a second browser to reach the product, the user is much closer to the point of purchase than a billboard or television advertisement. If advertisements or endorsements take place inside the game for real products that are readily available for purchase, those advertisements and endorsements should require the licensing of the identity.

Of course, if the commercial is for a "wacky package"233 or parody along the lines of Cardtoons ${ }^{234}$, then a lack of commercial payment and the parodic nature of the ad can be taken into account. A comedic TV sketch for a "Bass-o-Matic" remains a parody whether on television or playing on a television within a virtual world, ${ }^{235}$ so the placement of an advertisement within the virtual world should not materially affect the analysis. The determination should be based on whether the product is intended to be promoted to a gamer or viewer. If stadium billboards inside the game show celebrities endorsing commercially available products, those billboards should be treated the same as their brick-and-mortar counterparts. A commercial display of a product directly associated with a character or avatar should not be treated as transformative merely because the commercial appears in the game or virtual world.

The need to identify commercial endorsements and advertising for products that occur within the video games and virtual worlds suggests that the various tests of fair use, transformative use, and First Amendment must be applied to the specific use of the publicity rights within the game rather than more generally to the game as a whole. Similarly, the sale of virtual products with publicity rights or trademarks should be treated as commercial transactions if the sale results in an exchange of something of value that has economic consequence outside of the virtual environment.

Unlike the complex balancing surrounding the right fair use approaches to publicity rights protection, the concerns regarding the use of publicity rights and avatars within the video games and virtual worlds have a relatively simple regulatory solution. Broadcasting already has comprehensive rules for identification of paid sponsorships ${ }^{236}$ and e-mail advertising re-

233 Wacky Packages, http://www.wackypackages.com (last visited March 25. 2008) (Wacky Packages are magnets, stickers, and postcards which parody particular brand names such as "Canaduh Dry," "Enlisterine," and "Cavemanwich.")

234 Cardtoons, http://www.tilly.com/cardtoons/default.htm (last visited March 25, 2008) (Cardtoons are comic representations of sports athletes packaged as trading cards).

235 See Urban Dictionary, http://www.urbandictionary.com/define.php?term=bass-o-matic. (last visited January 16, 2008) ("Coined by SNL alumnus Dan Ackroyd in the 1970s, the bass-0-matic is an ordinary blender used to turn fresh bass (fish) into a disgusting red slurry that no one in his right mind would actually drink.") See also Suturday Night Live (NBC television broadcast April 17, 1976): Saturday Night Live Transcripts, http://snltranscripts.jt.org/75/75qbassamatic.phtml (last visited March 10. 2008).

236 47 U.S.C. $\$ 317$ (2000) ("Announcement of payment for broadcast rules"); 47 C.F.R. $\S$ 
quires disclosures. ${ }^{237}$ A simple extension of these laws would create a regulation requiring that paid advertising and sponsorships be identified for the user. Such a rule would not be difficult to implement, since the law could simply require a notice page of the endorsements, sponsorships and advertisers included in the product.

The relevance here is that the disclosure requirement would help define which uses of an avatar were in furtherance of a commercial purpose and which were expressive. If a person is depicted in a biographical movie drinking a Coke, there is no assumption that Coca-Cola paid to have its product associated with that famous person. Listing the companies paying for product placement might change that ${ }^{238}$ Consider a biographical movie of Humphrey Bogart and Lauren Bacall. Authenticity might require that the famed couple's actual cigarette brand preferences be shown, but there will be a tremendous financial temptation to create a sponsorship opportunity to sell the brand featured in the motion picture. Were such a production made for the Internet, a requirement that the advertisers be listed on a web page associated with the site would have little chilling effect. At the same time, the disclosure of commercial endorsement would help satisfy the public's compelling interest regarding the commercial promotion of products.

\section{Who Owns the Unauthorized Content, Anyway?}

Yet one additional wrinkle unique to the issues of virtual worlds is the ownership tension between the creators of content in the worlds and the publishers of the worlds themselves. Virtual world publishers require end user license agreements, which set forth the contractual rights of the gamer and the publisher ${ }^{239}$ The terms of service or end-user license agreements used in these relationships typically require that user not violate the rights of third parties and set forth the ownership of any intellectual property created or imported into the virtual world by the user.

Publishers try to immunize themselves from liability to third parties by including provisions in the agreements prohibiting the user from uploading content that violates the rights of third parties. ${ }^{240}$ As a result, to the ex-

\subsection{0 (2006) ("Payment disclosure: Payola. plugola. kickbacks").}

237 CAN-SPAM Act of 2003. Pub. L. No. 108-187, 117 Stat. 2699 (2003) (codified at 15 U.S.C. $\$ \$ 7701-7713$ and 18 U.S.C. $\$ 1037)$.

238 E.g., SUPERMAN II (Warner Brothers 1980) (the movie prominently featured the Coca-Cola sign which adorned Times Square). For an exact image, see also http://www.youtube.com/watch? $\mathrm{v}=68 \mathrm{hRt} 0 \mathrm{Pz} 7 \mathrm{HI}$, at time 2:05 of 2:26, (last visited March 10, 2008).

239 Erez Reuveni, On Virtual Worlds: Copyright and Contract Law at the Duwn of the Virtual Age, 82 IND. L.J. 261, 286-87 (2007); see generally, Steven J. Horowitz, Competing Lockean Claims to Virtual Property, 20 HARV. J.L. \& TECH. 443, (2007); Andrew E. Jankowich. Property and Democracy in Virtual Worlds, 11 B.U. J. SCI. \& TECH. L. 173 (2005); F. Gregory Lastowka \& Dan Hunter, The Laws of the Virtual Worlds, 92 CAL. L. REV. 1 (2004). The interpretation and enforceability of these agreements is beyond the scope of this article.

240 E g. Reuveni, supra note 239, at $286 \mathrm{n} .153$ (referring to a Sony end user license agreement). 
tent that the use of celebrity publicity rights violates the rights of the celebrities, such user conduct is a breach of the agreement. The consequences are typically set out in the agreement, but generally include the right of the publisher to terminate the user's account and prohibit the user from resubscribing. ${ }^{241}$

The specific contractual language may be important with regard to publicity rights. If the terms of service agreement were to specify copyright law and defamation, then publicity rights would be omitted from the prohibition. Were the prohibition written not to violate any other person's "intellectual property rights," then additional ambiguity would be introduced due to the inconsistency of the jurisdictions in labeling publicity rights as a personal right, property right, or intellectual property right.

The agreements may have a similar ambiguity with regard to the rights retained by the user and the publisher. Commercial sites often require that players waive any claims to the intellectual property created by the gamer inside the game and assign those rights to the publisher. ${ }^{242}$ In contrast, Second Life does not require the users to relinquish the intellectual property created and uploaded to the virtual world. ${ }^{243}$ Each publisher has a slightly different variation on the language used.

Assuming, arguendo, that no third party interests were violated by gamers when creating characters and avatars incorporating the publicity rights of athletes and performers, then under many of the license agreements, the copyrightable character created from the user's adaptation of the celebrity would become the property of the game publisher. The publishers, not the end users, would gain the economic value of these interests.

It will be highly ironic that courts would encourage a liberal interpretation of First Amendment jurisprudence to allow the creation of these avatars, only to have the rights then transferred by contract to the major commercial publishers by operation of click-wrap contract law.

\section{REORDERING CHAOS: COLLECTIVE BARGAINING AND BEST PRACTICES FOR THE PROFESSIONAL NEIGHBORHOODS OF VIRTUAL WORLDS}

At present, the courts reviewing claims for publicity rights have not been generous to their owners. Courts have been highly respectful of the free expression for the publishers of virtual worlds and computer games and slow to protect the property interests of athletes and performers. Were

$2+1$ E.g., Sony Online Entertainment LLC Terms of Service, http:/www.station.sony.con/tennsof service.vm (last visited January 15, 2008).

$2+2$ ll. see Reuveni, supru note 239, at 263-64.

243 See http://secondlife.com/corporate/tos.php, at section 3.2 (last visited Jan. 15, 2008) ("'S]ubject to the terms and conditions of this Agreement, you will retain any and all applicable copyright and other intellectual property rights with respect to any Content you create using the Service, to the extent you have such rights under applicable law."). 
this trend to continue, it will extend beyond virtual worlds to create a legal basis for challenging the type of exclusive deals presently being made by EA Sports and other publishers.

One response to the inconsistent and increasingly unfriendly judiciary could be an attempt to change the state laws or enact federal legislation. Such laws would inevitably face First Amendment challenges, raising even more questions regarding the scope of available protection. ${ }^{2+4}$ Moreover, to the extent that the judicial approach reflects the political will to protect celebrity interests, the efforts to protect these rights might result in substantial opposition in many jurisdictions. ${ }^{245}$

A preferred alternative would be for the professional athletes and actors to use their collective bargaining clout to establish an appropriate balance between the economic interests of the players and the expressive interests of the public and the publishers. Through collective bargaining and the establishment of recommended best practices, the celebrities are likely to gain an appropriate level of protection while respecting the free expression and creative interests important in the nuanced balancing between the First Amendment and the publicity rights. The collective bargaining agreements, in turn, should include provisions requiring that any other parties in business with the signatories to the collective bargaining agreements will also be required to commit to the practices required under the collective bargaining agreement. In this way the publicity rights provisions will extend beyond the bargaining unit to all commonly divisions under joint ownership with the employers, and eventually to many of their contracting partners.

\section{A. Collective Bargaining as an Alternative to Regulation}

Collective bargaining provides an excellent gap-filler for those areas in which intellectual property law cannot properly balance all inequities. ${ }^{246}$ The terms of the collective bargaining agreement can establish the rights to compensation, credit, and association of the person's identity with products or services. ${ }^{247}$ The existing collective bargaining agreements are moving from traditional film and television into Internet use and reuse of creative content developed by union members. ${ }^{2+8}$

2+4 Moreover, the analysis described throughout this article is limıted to United States law. Both the First Amendment and the publicity rights are highly idiosyncratıc to United States law but the foreign rules applying to publicity rights, though not dealt with in this article, will turn on different property and state interests, depending on the jurisdiction.

245 But see S.B. 771. 2007, Leg., Reg. Sess. (Ca. 2007) (amending CAL. CIV. CODE $\$ 3344.1$ to make retroactive publicity rights protection available to those who died prior to January 1,1985 ).

246 Cf. Toney v. L'Oreal, 406 F.3d 905, 910 (7th Cir. 2005) (discussing the Illinois Right of Publicity Act as a gap filler in intellectual property law); Fleet v. CBS, 50 Cal. App. 4th 1911, 1924 (Ct. App. 1996) (contract, not copyright or right of publicity, establishes the rights of an actor who voluntarly appears in a movie).

247 See Welch v. Carson Prods. Group. Ltd., 791 F.2d 13 (2d Cir. 1986).

24k Peter Sanders, Dircciors. Studios Reach a Deal, WAll St. J., Jan. 18. 2008, at A3. 
Welch v. Carson Productions Group ${ }^{24 y}$ provides an example of how the collective bargaining agreement provides a more nuanced solution to the tensions between publicity rights and production rights than the law can provide. Under section 36 of the Screen Actors Guild Television Agreement then applicable to the dispute, the reuse of a commercial required payment to the actors, but also provided a mechanism to allow the producers to use the commercial if the actor could not be identified or contacted. ${ }^{250}$ The provision balanced the performers' rights with very practical considerations regarding the transaction costs involving record keeping and reuse of content. The collective bargaining agreement specified the required minimum payments and set forth how the reuse would take place..$^{251}$ Unlike court decisions, the agreement provides rules for the situation in which the party cannot be located. In this fashion, the agreements can move beyond the legal rights of the parties to address the practical difficulties they face.

Collective bargaining agreements for actors and athletes generally reach issues of endorsement and commercial use of images, protecting performers from the unauthorized use of their images to commercialize a product. At the same time, the agreements provide explicit authority to use the identity interests of the performers to market, sell, and promote the audiovisual work in which the performer appears. As a result, all rights to place the image of an actor on the cover of a DVD case or on posters have been acquired.

For athletes, there are additional considerations. Because groups of players may be used for some commercial endorsements, the collective bargaining agreements have the ability to specify the interests of the player, the team, and the league. The rights of a player to use his or her team jersey, team logos, colors, etc., may prove essential to the ability of that player to commercially exploit his or her publicity rights. When a group of players collectively endorse a product, the team may have an economic or proprietary interest. Legal determinations regarding the scope of publicity rights are irrelevant to the balancing of these interests and their role in the overall bargain between the performers and their employers. The collective bargaining agreement is the law of the deal.

Under a collective bargaining approach to exploitation of publicity

249791 F.2d 13.

250 "Reuse of Photography or Sound Track." provides that a producer may not reuse television film of an actor in a manner other than that for which the actor originally was employed

without separately bargaining with the player and reaching an agreement regarding such use. ... [If] the Producer is unable to find the player. it shall notify the Guild [SAG], and if the Guild is unable to find the player within a reasonable time, the Producer may use the photography. .. without penalty,...

Id. at 14-15 (quoting 1977 Screen Actors Guild Television Agreement ("Green Book") \$ 36) (citations omitted) (omissions in original).

251 Id. 
rights in video games and virtual worlds, the publishers receive the right to use the identity of a celebrity for noncommercial, expressive activities in exchange for clear prohibitions against using the identity for commercial exploitation. In keeping with this basic approach, the following points would need to be negotiated:

The right of publicity would have to be recognized by the publishers and producers of the video games, websites, and virtual worlds. The right would extend to members of the bargaining unit as well as any other person, except for non-union members appearing in crowds or large groups. ${ }^{252}$

The definition of commercial activity would be specified to focus on the sale, marketing, or endorsement of any product or service offered to the public. It would exclude all expressive, literary or editorial content, and provide limited use of unlicensed identity interest for advertising or marketing of the work in which the celebrity appeared as a performer or athlete.

The publishers and producers would be obligated to make an effort ${ }^{253}$ to avoid interfering with the exploitation of the publicity rights by union members with products or services which were in competition with the products and services for which the union members had existing exclusive arrangements. For example, because Tiger Woods has an exclusive endorsement agreement with Nike, ${ }^{254}$ absent a compelling editorial need, he would be depicted with a Nike shirt rather than a Reebok shirt. Similarly, Serena Williams would be shown using a Hewlett-Packard computer rather than an Apple to recognize her exclusive agreement with the manufacturer, HP. ${ }^{255}$ Such a rule would not be absolute, however, and would allow for necessary editorial use by the publishers, including the ability to parody or satirize the endorsements.

For athletes, collective bargaining agreements with teams and leagues would need to extend to the use of identity interests in computer games and virtual worlds. The publishers and producers would be required to recognize those agreements either by becoming signatories or recognizing the third party beneficiary interests and obligations set forth in the players' collective bargaining agreements.

The enforcement of the publicity rights provisions would need to ex-

252 The difference between an outline of the terms and the specific terms is highlighted by this concept. While it may be intuitively easy to understand when a person is featured in an advertisement and when a person is merely part of the background, the language necessary to make that distinction may be highly technical and beyond the scope of this article.

253 Such a clause could range from a contractual requirement to a reasonable efforts obligation. A "best efforts" clause would be a reasonable starting point. 254 Jason Sobel, Woods Signs Third Multivear Deal with Nike Golf. ESPN.cOM, Dec. 13, 2006,
http://sports.espn.go.com/golf/news/story?id=2695135.

255 See Susan Dominus, Dangerous When Interested. NYTIMEs.com, Aug. 19, 2007, http://www.nytimes.com/2007/08/19/sports/playmagazine/0819play-serena.html: Kate Maddox, HP
Serves up TV Spot, B TO B ONLNEE Aug Serves up TV Spot, B To B ONLINE, Aug. 27, 2007, http://www.btobonline.com/apps/pbcs.dll/article?
AID=/20070827/FREE/70827004/1078. 
tend beyond the publisher or producer of the game or site to include the end users. The publishers and producers would accomplish this through inclusion of the provisions in its end-user license agreement. ${ }^{256}$

Rules governing the importation of content originally created for television, radio, billboard, and motion pictures should be developed. This will allow for better movement of advertising and other content to the games and virtual worlds. For example, a depiction of a drive-in theatre in a virtual world could be running movie trailers, movies, or commercials, and the availability of this use must be obtained from both the copyright holder and the performers. Billboards and print advertising should similarly be clarified.

Compensation would be paid to the performers. The competition might be limited to the commercial exploitation only or could be based on other uses. Compensation might even be appropriate in situations such as PRO, where substantial revenues are being generated based on the union 'members' identities notwithstanding the fact that those identities are used in an expressive manner. This reflects the distinction between the editorial control over the image and the economic advantage being taken by the use of the image. Such compensation deals, however, would be appropriate only where a very substantial taking of identity interests occurred.

Credit for the performers would be provided and full disclosure of the relationship between the celebrities and the characters and avatars would make explicit the extent to which permission had been granted for the depictions in each game or virtual world.

The terms of the agreement will apply to all divisions under the common ownership of the producers. The parties to the agreement will not enter into agreements with any third party that does not abide by a substantially similar agreement or an enforceable statement of best practices.

The producers will provide a notice and take-down mechanism for complaints of publicity rights infringement similar to that utilized for complaints of copyright infringement. ${ }^{257}$

The particular rule adopted under each of these topics does not necessarily matter. Different unions will likely seek different outcomes, at least initially. Actors, musicians, and athletes may each have slightly different goals for the agreements, and these differing interests will result in slightly different resolutions. Parties will learn from each other as a consensus emerges. The rules provide a much more symbiotic relationship between the parties than any that can be derived through court decisions.

250 See Andrew Jankowich, EULAw: The Complex Web of Corporate Rule-Making in Virtual Worlds. 8 TUL. J. Tr.CH. \& INTELL. PROP. 1 (2006): Robert L. Oakley, Fairness in Electronic Contracting: Minimum Standards for Non-Negotiated Contracts, 42 Hous. L. REV. 1041 (2005).

257 Sce 17 U.S.C. $\$ \$ 12$ (2000) (enacting limitations on liability relating to material online); see also 47 U.S.C. $\$ 230(2000)$ (providing protection lor private blocking and screening of offensive material) 


\section{B. Expanding the Jurisdiction through Viral Distribution of the Agreements}

To be effective, these provisions must ultimately be fairly ubiquitous across the Internet. Although content on the Internet is not directly regulated, many policies derive from regulation ${ }^{258}$ or commonly adopted practices. $^{259}$ A contract provision, such as the one suggested above in paragraph nine, that requires the contracting party to enter the same clause with its other contracting partners takes on the behavior of a virus, 'infecting' every contracting party that comes into contact with the source of the provision. These provisions provide that the parties to the first contract are a form of third party beneficiary to the subsequent agreements. Assuming these provisions are drafted in a manner consistent with antitrust laws, ${ }^{260}$ such provisions can quickly transform the common practices of an industry.

A practice codified into collective bargaining agreements for those companies which are unionized ${ }^{261}$ and followed as best practices for those businesses which have no union agreements will be applicable for a major portion of the commercially significant activities on the Internet. The technique for spreading new contractual expectations through viral provisions in contracts will not extend everywhere, but it should track most of the economically relevant activity. Through the combination of contractual and voluntary adoptions, voluntary self-regulation spread virally through the transactional web of the Internet.

The plan to regulate publicity rights in gaming and virtual worlds through collective bargaining may appear flawed because the jurisdiction appears too limited on both sides. The Wild West of the Internet is not home to extensive collective bargaining agreements. A closer look, however, suggests that through the application of these viral contracting techniques, there is both the ability to marshal collective bargaining power clout and the economic interests to do so. This is not a case of traditional

258 E.g , 42 U.S.C. \$ 1320d-2 (2000) (HIPAA regulations attaching data security obligation to any entity having control over the regulated health information).

259 An example of this would be voluntary ratings for motion pictures or video games. See Motion Picture Association of America, Film Ratings, http://mpaa.org/filmratings.asp (last visited Mar, 9. 2008); Entertainment Software Rating Board, http://www.esrb.org (last visited Mar. 9, 2008). Professor Larry Lessig would suggest that the computer code utilized to standardize Internet sites has this de facto effect. LAWRENCE LESSIG. CODE AND OTHER LAWS OF CYBERSPACE 6 (1999).

260 Sherman Act, 15 U.S.C. $\$ 1(2000)$. See Lawrence A. Cunningham. Language, Deals, and Standards: The Future of .YML Contracts, 84 WASH, U. L. REV. 313 (2006): Henry H. Perritt. Jr.. Towards a Hybrid Regulatory Scheme for the Internet, 2001 U. CHI. LEGAL F. 215. 285-88 (2001).

201 The non-statutory labor exemption from antitrust laws avoids Sherman Act complications when the parties are involved in good fatth bargaining regarding topics such as wages, hours, and working conditions. Brown v. PRO Football, Inc., 518 U.S. 231, 236 (1996); Connell Constr. Co. v. Plumbers \& Steamfitters Local 100, 421 U.S. 616, 622 (1975). While the antitrust implications are significant, they are not likely to interfere with a broadly adopted set of policies, particularly if the policies were generally consistent with, and clarifying of, existmg law. Such practices would be reasonable and efficient, benefiting competition and trade. and therefore upheld under either the exemption or under a rule of reason analysis. See Connell, 421 U.S. 616. 
labor-organizing. The avatars will not be holding rallies, collecting cards, or counting votes. Instead, the willingness to enter into collective bargaining talks will stem from the leverage held by the players and performer unions.

Many of the most important aspects of the Internet are operated by entities that are owned by companies, which in turn have agreements with one or more of the relevant bargaining agreements. ${ }^{262}$ America Online is part of AOL/Time Warner. ${ }^{263}$ AOL also has a working agreement with Google. Disney has extensive ownership of websites as well as ownership of ESPN and related properties. News Corp., the parent company of Fox, owns MySpace among other sites. ${ }^{264}$

In the video game industry, there is much greater consolidation. Sony is the manufacturer of one of the three principle video game platforms. ${ }^{265}$ Microsoft, the maker of a second such player, has co-owned brands with General Electric's NBC. ${ }^{266}$ Only Nintendo has no cross-over ownership interest, but it has media content, such as Pokémon, which is sold for broadcast. $^{267}$

Under the viral approach to enforcing the collective bargaining agreements, the performers' unions initially negotiate for the relevant provision in collective bargaining agreements with the producers presently under contract. The ninth provision, listed above, requires that the members of the producers or league enforce the agreement by requiring the provisions to be adopted by their contracting partners. In the first instance, this would require that the entirety of a commonly owned enterprise be subject to the rules. The rules would become the "law" everywhere within the empires of GE, Sony, News Corp., Viacom, CBS, or Disney. Broadcasters would feel the pressure from both the actors' union and the players' union and leagues.

There would, naturally, be some resistance to the proposal because payments are required. But each of these companies also own large portfolios of brands. ${ }^{268}$ These companies utilize endorsements to promote many of their own brands, and they make significant revenue from advertisers that seek efficient methods to protect the investment in the performers who endorse their products. As a result, broadcasters, advertisers, and performers all have the same interest in promoting a system that recognizes legal

262 The Nation provides an excellent visual representation. See Forum, The National Entertainment State, THE NATION, July 3, 2006, at 23-26, available at http://www.thenation.com/special/ 2006_entertainment.pdf [hereinafter National Entertainment State].

263 ld.

$264 \mathrm{ld}$.

265 The three principle video game platforms are Sony's Playstation 3, Microsoft's Xbox 360. and the Nintendo Wii.

266 GE, Microsofi Bring Bigolm to Life. FaIRNESS \& ACCURACY IN REPORTING, Feb. 12, 2003, $\mathrm{http} . / / \mathrm{www}$. fair.org/Index.php?page= 1632 (discussing the co-ownership of the news station. MSNBC).

26.7 Pokèmon, http.//www.pokemon.com/\#tvmovies (last visited Mar. 21, 2008).

20* See National Entertainment State, supra note 262. 
protections. Properly managed, a campaign by celebrities to win over the advertisers and the leagues would emphasize their common interests.

The negotiations will also be more successful if the balance sought is reasonable and consistent with the historical copyright fair use and free expression approach to balancing ownership and expression. Publishers will appropriately fight attempts to frustrate biographies or unauthorized uses of identities. Producers will defend the right to produce parodies of celebrities on television and on the Internet. The rules outlined for the collective bargaining agreement must not impinge on these acts of commentary, criticism, and public discourse.

Once the provisions are incorporated into existing collective bargaining agreements and applied to the enterprises in which those bargaining units exist, the obligation to recognize these rights will spread quickly throughout much of the industry. Sony will impact a large percentage of the video game producers. Google, Yahoo, and YouTube will be brought in through advertising agreements with the various content providers. As a result of contractual relations among the major content producers and advertisers, many of the sources of advertising will be contractually obligated to follow the rules.

The jurisdiction will extend slowly throughout the Internet, computer gaming, and virtual world environment to provide protection for union members and non-union members alike. In this way, it will reach college athletes and non-union musicians as well as the professional celebrities who are notorious rather than talented. Although unions are often reluctant to extend union benefits beyond their members, such protection is in the union's economic best interest because it precludes the signatory from reducing cost by approaching non-union performers for their rights.

\section{Best Practices for Everyone Else}

There are limits to the model of viral contracting as a method of revising the normative behavior on the Internet. First, the collective bargaining and contract negotiating process intentionally spreads the obligation somewhat slowly through the media network. Second, the reach does not extend to publishers like PRO, which are user-created or outside traditional media. Both of these limits are benefits of the approach.

For the rules of publicity to gain widespread acceptance, the rules need to become part of the normative balance of rights expected by the public. Both copyright ${ }^{269}$ and trademark ${ }^{270}$ allow the scope of enforcement to be based on the behaviors and expectations of the public. While not al-

269 See Jon M. Garon, Nomative Copıright: A Conceptual Framework for Copvright Philosophy and Ethics, 88 CORNELL L. REV 1278 (2002) (emphasizing the fact that the public's acceptance of practices establishes fair use).

270 See Two Pesos, Inc. v. Taco Cabana, Inc. 505 U.S. 763, 780 (1992). 
ways effective, ${ }^{271}$ law in general and intellectual property law in particular benefits tremendously from having it reflect accepted behavior rather than trying to preclude conduct the public does not generally find inappropriate.

Particularly within the context of virtual worlds, there needs to be a great deal of experimentation before the genre matures. Some of these experiments will be highly popular and successful; most will go unnoticed. Owners of intellectual property rights will waste valuable resources if they futilely try to chase every act of infringement. They will also stymie the very innovation necessary for the next stage in growth for immersive and interactive media.

The use of a viral licensing regime helps align the economic interests of the parties and leaves those parties with few connections generally out of the private ordering. As an unlicensed project gains momentum, it is likely to need contractual relations with an entity under the licensing regime. At that point, the publishers can choose to join the regime or stop growing in order to avoid those contractual entanglements.

The best practices are even simpler than the provisions needed in the collective bargaining agreement, because the duties are self-imposed, not requiring any provisions for enforcement outside of the virtual world under operation:

1. The right of publicity would have to be recognized by the virtual world.

2. The enforcement of the publicity rights provisions would need to extend beyond the publisher or producer of the game or site to include the end-users.

3. The definition of commercial activity would be specified to focus on the sale, marketing, or endorsement of any product or service offered to the public. It would exclude all expressive, literary or editorial content, and provide limited use of unlicensed identity interest for advertising or marketing of the work in which the celebrity appeared as a performer or athlete.

4. The virtual world and its members would be obligated to make efforts to avoid interfering with the exploitation of the publicity rights by celebrities with products or services which were in competition with the products and services for which the celebrity had existing exclusive arrangements.

5. Use of publicity rights for commercial activities can only be conducted with the permission of the celebrity.

6. Credit for the performers would be provided and full disclosure of the relationship between the celebrities and the characters and avatars would make explicit the extent to which permis-

271 See, e.g.. Metro-Goldwyn-Mayer Studios, Inc. v. Grokster, Ltd., 545 U.S. 913 (2005); A\&M Records, Inc. v. Napster, Inc., 239 F.3d 1004 (9th Cir. 200l). 
sion had been granted for the depictions in each game or virtual world.

7. The producers will provide a notice and take-down mechanism for complaints of publicity rights infringement similar to that utilized for complaints of copyright infringement.

These provisions are very similar to the provisions applied to collective bargaining agreements, and should be relatively easy for operators of virtual worlds to add to the end-user license agreements and as practices governing their own conduct.

Over time, many of the entities not otherwise contractually obligated to accept the provisions will choose to adopt them as best practices. If the policies are well balanced and take into account both the social desire for robust expression and the social desire for accurate, fully-disclosed commercial endorsements, then publishers of websites will recognize that the burdens of the provisions are very minor and the benefits to the site 's customers are significant.

\section{CONCLUSION}

The use of new rules for publicity rights in computer games and virtual worlds are best developed through creation of a best practices standard and a series of collective bargaining agreements that slowly pervade the online and gaming worlds. These rules can provide robust protection for celebrities when their identity is hijacked to sell or endorse products, while promoting wide latitude for writers, artists, and publishers to use the identity when telling stories about the celebrities or merely using celebrities as the raw material for other expressive works.

Private ordering will allow for this newest of intellectual property rights to mature, and would avoid the widespread confusion created by the multiple tests proliferating among the courts and the somewhat inconsistent application of the publicity rights doctrine alongside copyright and trademark law.

Given the importance of virtual worlds in the future social fabric, a solution to the identity rights chaos is necessary. Already protected by constitutional law, these worlds' content reflects an important new platform for public discourse, as ideas and mores are explored within these environments. At the same time, these worlds are also sites of commercial transactions, advertising, marketing, and endorsements that take advantage of performers, athletes, and other celebrities to sell their wares.

Celebrities are likely to embrace this new opportunity only if their intellectual property interests can be protected. Through the combination of collective bargaining agreements and best practices, the problems of court interpretation can be avoided, First Amendment challenges averted, and legitimate rights protected.

Let the games continue. 
